\title{
Insights into methane dynamics from analysis of authigenic carbonates and chemosynthetic mussels at newly-discovered Atlantic Margin seeps
}

\author{
Prouty $^{1 *}$, N.G., Sahy ${ }^{2}$, D., Ruppel ${ }^{3}$, C.D., Roark ${ }^{4}$, E.B., Condon ${ }^{2}$, D., Brooke ${ }^{5}$, S., Ross ${ }^{6}$, S.W . \\ Demopoulos ${ }^{7}$, A.W.J. \\ ${ }^{1}$ US Geological Survey, Pacific Coastal and Marine Science Center, 400 Natural Bridges Drive Santa Cruz, CA \\ 95060 nprouty@usgs.gov \\ ${ }^{2}$ Department of Geography, Texas A\&M University, College Station, TX 77843 \\ ${ }^{3}$ NERC Isotope Geosciences Laboratory, British Geological Survey, Nicker Hill, Keyworth NG12 5GG \\ UK \\ ${ }^{4}$ US Geological Survey, Woods Hole Coastal and Marine Science Center, Woods Hole, MA 02543 \\ ${ }^{5}$ Florida State University, Coastal and Marine Laboratory, 3618 Coastal Highway 98 St. Teresa, FL 32358 \\ ${ }^{6}$ University of North Carolina-Wilmington, Center for Marine Science, 5600 Marvin Moss Ln, Wilmington, NC \\ 28409 \\ ${ }^{7}$ US Geological Survey, Wetland and Aquatic Research Center, 7920 NW 71 ${ }^{\text {st }}$ St., Gainesville, FL 32653 \\ *corresponding author
}

\begin{abstract}
The recent discovery of active methane venting along the US northern and mid-Atlantic margin represents a new source of global methane not previously accounted for in carbon budgets from this region. However, uncertainty remains as to the origin and history of methane seepage along the tectonically inactive passive margin. Here we present the first isotopic analyses of authigenic carbonates and methanotrophic deep-sea mussels, Bathymodiolus sp., and the first direct constraints on the timing of past methane emission, based on samples collected at the upper slope Baltimore Canyon ( 385 m water depth) and deepwater Norfolk $(\sim 1600 \mathrm{~m})$ seep fields within the area of newly-discovered venting. The authigenic carbonates at both sites were dominated by aragonite, with an average $\delta^{13} \mathrm{C}$ signature of $-47 \%$, a value consistent with microbially driven anaerobic oxidation of methane-rich fluids occurring at or near the sediment-water interface. Authigenic carbonate $\mathrm{U}$ and $\mathrm{Sr}$ isotope data further support the inference of carbonate precipitation from seawater-derived fluids rather than from formation fluids from deep aquifers. Carbonate stable and radiocarbon $\left(\delta^{13} \mathrm{C}\right.$ and $\left.\Delta^{14} \mathrm{C}\right)$ isotope values from living Bathymodiolus sp. specimens are lighter than those of seawater dissolved inorganic carbon, highlighting the influence of fossil carbon from methane on carbonate precipitation. U-Th dates on authigenic carbonates suggest seepage at Baltimore Canyon between $14.7 \pm 0.6 \mathrm{ka}$ to $15.7 \pm 1.6 \mathrm{ka}$, and at the Norfolk seep field between $1.0 \pm 0.7 \mathrm{ka}$ to $3.3 \pm 1.3 \mathrm{ka}$, providing constraint of the longevity of methane efflux at these sites. The age of the brecciated authigenic carbonates and the occurrence of pockmarks at the Baltimore Canyon upper slope could suggest a link between sediment delivery during Pleistocene sea-level lowstand, accumulation of pore fluid overpressure from sediment compaction, and release of overpressure through subsequent venting. Calculations show that the Baltimore Canyon site probably has not been within the gas hydrate stability zone (GHSZ) in the past $20 \mathrm{ka}$, meaning that in-situ release of methane from dissociating gas hydrate cannot be sustaining the seep. We cannot rule out updip migration of dissociating methane hydrate that occurs farther down the slope as a source of the venting at Baltimore Canyon, but consider that the history of rapid sediment accumulation and overpressure may play a more important role in methane emissions at this site.
\end{abstract}


Key words: authigenic carbonate; cold seep; AOM; chemosynthesis; mid-Atlantic margin; isotope geochemistry

\section{Introduction}

The distribution of newly discovered seafloor methane seeps along the US Atlantic margin (USAM) (Skarke et al., 2014) has important implications for ocean carbon dynamics (Boetius and Wenzhöfer 2013), continental slope stability and related hazards (Dugan and Flemings 2000; ten Brink et al. 2014), and also the geographic extent of chemosynthetic communities (Quattrini et al. 2015). Whereas seafloor methane venting typically occurs in major hydrocarbon basins such as the Gulf of Mexico or on active margins such as Cascadia, the northern USAM passive margin had long been considered relatively inactive (Skarke et al., 2014). Methane seeps have been documented on the southern USAM, at Cape Fear (L. Brothers et al. 2013) and Blake Ridge (Paull et al. 1995; Van Dover et al. 2003), where they occur at a depth range of 2155 to $2600 \mathrm{~m}$ above rising salt diapirs that perturb that gas hydrate stability field (Hornbach et al., 2005), but no such features were known on the northern part of the margin. This assessment was revised when geophysical surveys conducted between 2011 and 2013 identified $~ 570$ gas plumes at water depths of 50-1700 m between Cape Hatteras and Georges Bank (Skarke et al. 2014). Observations at a few of the sites from remotely operated vehicles (ROV) included bubble streams, bacterial mats, chemosynthetic communities, authigenic carbonates, deep-sea corals, and gas hydrate (Skarke et al., 2014; Quattrini et al. 2015). Average contemporary methane emissions from seeps along the entire northern USAM are estimated at $\sim 15$ to $90{\mathrm{Mg} \mathrm{yr}^{-1}}^{-1}$ (equivalent to 0.95 to $5.66 \times 10^{6} \mathrm{~mol} \mathrm{yr}^{-1}$ ) based on analysis of ROV bubble observations (Skarke et al. 2014), versus 2.15 to $8.65 \times 10^{6} \mathrm{~mol} \mathrm{yr}^{-1}$ in a seep field of Hudson Canyon based on the water column methane concentrations (Weinstein et al., 2016). 
The origin and characteristics of the methane seeps north of Cape Hatteras remain elusive. No underlying salt diapirs have been documented in the seeping areas, and Skarke et al. (2014) postulate that dissociation of gas hydrate and possibly submarine groundwater discharge may play a role in feeding seeps between the outer continental shelf and uppermost continental slope, while the deeper seeps represent leakage of methane through fractured Eocene rocks. Distinguishing among these and other processes that may be responsible for the methane emissions requires direct study of seep fluids, rocks, and organisms. To acquire samples for such studies, the Bureau of Ocean Energy Management (BOEM), the U.S. Geological Survey (USGS), the National Oceanic and Atmospheric Administration (NOAA), and their academic partners initiated a 5-year multi-disciplinary "Atlantic Deepwater Canyons" study focusing on ecologically significant habitats (canyons, cold seeps, hard-bottoms and shipwrecks) in Norfolk Canyon (off Virginia) and overlooking Baltimore Canyon (off Maryland) (Fig. 1). Of the two sites, Baltimore Canyon had been previously investigated in the early 1980s with photographs of a dense community of mussels at $\sim 400 \mathrm{~m}$ obtained using a towed camera sled (B. Hecker, pers. comm.), but no further work was conducted in the area until recently. During the Atlantic Deepwater Canyons cruises, we used ROVs designed to support physical and biological sampling to confirm the location of a shallow ( $400 \mathrm{~m})$ seep site overlooking Baltimore Canyon in 2012 and, following the discovery of deep-sea gas plumes (NOAA, 2012), identified a new chemosynthetic community at $\sim 1600$ m water depth south of Norfolk Canyon in 2013.

Authigenic carbonates are common at cold seeps and record a robust fingerprint of hydrocarbon seep activity, including local and regional controls on the source and flux of carbon, the conditions under which carbonates formed, and information regarding fluid-sediment and rock 
interactions (see reviews in Campbell et al., 2006; Suess 2014). Additionally, authigenic carbonates are amenable to uranium (U)-series dating techniques, and can provide key information on the timing and duration of fluid venting at each seep (Teichert et al. 2003; Bayon et al. 2009; Liebetrau et al., 2014). The isotopic composition of shells from chemosynthetic bivalves living close to fluid vents represents an important archive of the nature and variability of the venting. While previous studies have investigated authigenic carbonate formation and cold seeps in other settings (Han et al., 2014; Suess 2014; Bayon et al., 2015) and fluid flow in passive margins (Berndt 2005), this is the first study to examine the origin of the authigenic carbonates, the source fluids, and the timing of methane emissions on the northern USAM. This paper explores the geochemistry, mineralogy, and petrology of authigenic carbonates and bivalve shells recovered by ROVs from both the Norfolk and the Baltimore Canyon seep fields with the aim of tracing the origin and flow pathways of gas and fluids at both sites. Taken together, the geochemical information derived from both authigenic carbonates and bivalve shells collected from seeps in the Baltimore and Norfolk canyons expands our understanding of the origin and occurrence of widespread methane seepage along the US Mid-Atlantic margin

\section{Methods}

\subsection{Study site}

A shallow ( $\sim 385 \mathrm{~m}$; Fig 2) seep site seaward and south of the location where Baltimore Canyon $\left(38^{\circ} 03.086 \mathrm{~N}, 73^{\circ} 49.379 \mathrm{~W}\right)$ crosses the shelf-break was surveyed and sampled during a 2012 cruise (17 Aug-14 Sep) aboard the NOAA ship Nancy Foster using the Kraken II ROV (University of Connecticut). This site was sampled again in 2013, along with the deeper (14551610 m; Fig. 3) Norfolk seep site ( $36^{\circ} 51.921$ N, $74^{\circ} 29.574 \mathrm{~W}$ ) during a cruise (2-18 May) 
onboard the NOAA ship Ronald H. Brown using the Jason II ROV (Woods Hole Oceanographic Institution). At the Norfolk seep site, gas bubbles can be traced at least $\sim 600 \mathrm{~m}$ above the seafloor (Fig. 3C), as confirmed by USGS surveys on the $R / V$ Endeavor in April 2015 (Ruppel et al., 2015a). At the Baltimore Canyon seep field, water column imaging carried out by the USGS in April and September 2015 (Ruppel et al., 2015b) showed that venting is more widespread and diffuse (Fig. 2D). Dense colonies of chemosynthetic mussels, active gas bubbling, and extensive bacterial mats were observed at both seep sites (Fig. 2C and 3D) during the 2012 and 2013 ROV dives. Clams, common at the Blake Ridge seep site (Van Dover et al. 2003), were notably absent, as were tubeworms, a finding that is consistent with a recent survey of chemosynthetic communities from seep sites along the northeastern US continental margin (Quattrini et al., 2015). Seep communities at the Norfolk and Baltimore Canyon seep fields were dominated by the deep-sea mussels of the genus Bathymodiolus, which depends on chemosynthetic endosymbiotic bacteria to oxidize sulfur and/or methane for nutrition (Duperron et al. 2011).

\subsection{X-Ray diffraction and petrography}

Sample mineralogy was determined microscopically in thin sections, and by X-ray diffraction (XRD) using a Philips XRD with graphite monochromator at $40 \mathrm{kV}$ and $45 \mathrm{~mA}$. Step scans were run from $5^{\circ}$ to $65^{\circ} 2 \theta$ with $0.02^{\circ}$ steps, using $\mathrm{CuK} \alpha$ radiation and a count time of $2 \mathrm{~s}$ per step. XRD digital scan data were analyzed using the Philips X'Pert High Score search-and-match function to identify minerals. Mineral percentages were determined by multiplying unique peak intensities for each mineral in a sample by relative intensity factors. The products for all minerals in each sample were then summed to $100 \%$. Carbonate content, reported as weight 
percent (wt $\%$ ), was determined using a coulometer at the USGS Pacific Coastal and Marine Science Center, Santa Cruz, CA.

\subsection{Stable isotopes}

Stable carbon $\left(\delta^{13} \mathrm{C}\right)$ and oxygen $\left(\delta^{18} \mathrm{O}\right)$ isotopes were analyzed at the Stable Isotope Geosciences Facility at Texas A\&M University. Authigenic carbonate samples were subsampled to isolate the cement and groundmass components. For the mussel shells, carbonate and periostracum (organic rich outer layer) were collected along transects from the umbo to the ventral margin of an individual specimen at discrete distances. Prior to analysis, the periostracum material was acidified to remove inorganic carbon. Data were generated from a Thermo-Finnigan MAT 253 with a Kiel IV Automated Carbonate Prep Device and are reported in per mil (\%) relative to the international reference Pee Dee Belemnite (PDB). Analytical uncertainties $(2 \sigma)$ of $0.04 \%$ for $\delta^{13} \mathrm{C}$ and $0.06 \%$ for $\delta^{18} \mathrm{O}$ are reported based on the long term daily measurements of the international carbonate standard, NBS-19. Seawater samples were measured for $\delta^{18} \mathrm{O}$ using a Picarro L2120i cavity ringdown spectrometer at the Stable Isotope Geoscience Facility at Texas A\&M University, College Station. Isotope values were calibrated to the VSMOW reference standard using internal reference standards JGULF and KONA. The $\delta^{18} \mathrm{O}$ value in VSMOW2 for JGULF is $1.22 \%$, and for Kona is $-6.86 \%$. Average internal $\delta^{18} \mathrm{O}$ precision is $0.12 \%$, and an external precision replicate of the same sample is $0.26 \%$.

Sulfur isotopes $\left(\delta^{34} \mathrm{~S}\right)$ were determined at the Washington State University Stable Isotope Core Laboratory. Mussel gill and seep sediment were combusted with an elemental analyzer (ECS 4010, Costech Analytical) coupled to a Delta PlusXP Thermo-Finnigan continuous flow isotope 
ratio mass spectrometer. Sulfur isotope ratios $\left(\delta^{34} S\right)$ are reported in per mil (\%o) relative to VCDT (Vienna Canyon Diablo Troilite). Analytical accuracy $(1 \sigma)$ of $\delta^{34} S$ was determined by replicate analysis of internal lab standard referenced to IAEA standards, reported as $0.26 \%$ o $(n=36)$, bovine internal standard at $0.47 \%$ o $(n=18)$ and sample replicates $0.13 \%$ o $(n=9)$.

\subsection{Strontium isotopes}

The strontium isotope $\left({ }^{87} \mathrm{Sr} /{ }^{86} \mathrm{Sr}\right)$ compositions of the authigenic carbonates, mussel shells, and seawater samples were determined at the USGS facility at Menlo Park, California. Bottom water samples were filtered using a $0.45 \mu \mathrm{m}$ glass fiber filter. Authigenic carbonate samples were subsampled to isolate the cement and groundmass components, and mussel shell material was homogenized using an agate mortar and pestle. The mussel shell and authigenic components were leached to remove labile $\mathrm{Sr}$ and digested in sealed Teflon vessels. Sr was separated from other ions using a Bio-Rad® AG-502-X8 cation exchange resin with $\mathrm{HCl}$ as the eluent. Purified Sr was converted to nitrate form, taken up in $30 \mu \mathrm{L}$ of $0.15 \mathrm{M} \mathrm{H}_{3} \mathrm{PO}_{4}$ and loaded onto a Ta ribbon for mass spectrometric measurement. The isotopic composition was measured on a Finnigan MAT 261 multi-collector mass spectrometer using a static collection mode. All reported values of ${ }^{87} \mathrm{Sr} /{ }^{86} \mathrm{Sr}$ have been corrected for analytical fractionation to the standard ${ }^{88} \mathrm{Sr} /{ }^{86} \mathrm{Sr}$ ratio of 8.37521 , and measurements are precise to \pm 0.00002 at the $95 \%$ confidence level.

\subsection{Radiocarbon $\left({ }^{14} \mathrm{C}\right)$ analysis}

Radiocarbon $\left({ }^{14} \mathrm{C}\right)$ analysis was performed on subsamples of authigenic carbonates and mussel shells collected from dead and live mussel specimens. Samples were prepared for Accelerator 
Mass Spectrometry (AMS) radiocarbon $\left({ }^{14} \mathrm{C}\right)$ dating at the Keck Carbon Cycle AMS laboratory at UC Irvine (KCCAMS). Authigenic carbonate samples were subsampled to isolate the cement and groundmass components. Carbonate from the mussel shells was analyzed both as a homogenized powder as well as shell fragments. To test for potential contamination by secondary aragonite or calcite, duplicates were performed on samples treated with $10 \% \mathrm{HCl}$.

The carbonate samples were hydrolyzed to $\mathrm{CO}_{2}$ in individual reaction chambers, evacuated, heated and acidified with orthophosphoric acid at $90^{\circ} \mathrm{C}$. The resultant $\mathrm{CO}_{2}$ was converted to graphite using an iron catalyst and the hydrogen reduction method (Vogel et al. 1987). Sample preparation backgrounds have been subtracted, based on measurements of ${ }^{14} \mathrm{C}$-free calcite and oxalic acid I. All ${ }^{14} \mathrm{C}$ results were corrected for isotopic fractionation according to the conventions of Stuiver and Polach (1977) with $\delta^{13} \mathrm{C}$ values measured on prepared graphite using the AMS spectrometer. Radiocarbon concentrations are given as $\Delta^{14} \mathrm{C}$ and conventional radiocarbon age following Stuiver and Polach (1977).

\subsection{U-Th age dating of authigenic carbonates}

U-Th dating of authigenic carbonates was carried out at the NERC Isotope Geosciences Laboratory, British Geological Survey. Samples were processed via total dissolution techniques, with isotope ratios measured on a Thermo Neptune Plus multi-collector ICP-MS, relative to a mixed ${ }^{229} \mathrm{Th}^{236} \mathrm{U}$ tracer calibrated against gravimetric solutions of CRM 112a U and Ames laboratory high purity Th. Details of the analytical protocol are provided in the Supplementary Material. U-Th age calculations were performed using an in-house Excel spreadsheet, and are calculated using the decay constants of Cheng et al. (2013). 


\section{Results}

\subsection{X-Ray diffraction and petrography}

Calcium carbonate $\left(\mathrm{CaCO}_{3}\right)$ dominates the authigenic carbonate samples $(48-97 \%)$ but not the surrounding sediment (3-14\%) (Table 1). Aragonite accounts for more than $60 \%$ of the groundmass and up to $99 \%$ of the carbonate cement, with secondary amounts $(<15 \%)$ of low and high-Mg calcite present, creating an aragonite-cemented intraclast breccia at both sites (Fig. S1). The detrital fraction consists of poorly sorted accessory minerals, such as quartz, feldspar, plagioclase, and pyroxene that are supported in a matrix of clay to silt-size particles, consistent with grain size from the surrounding sediment. The clasts are sub-rounded to very angular, particularly in the Baltimore Canyon specimen (Fig. 4). Voids between intraclasts and bivalve shells are completely or partially filled with fibrous or bladed aragonite, showing multiple generations of mineral growth. Fractures intersect well-developed radiating crystals of aragonite in the Baltimore Canyon sample. Bioclasts are observed in both samples, either as intact shells, aragonite filled, or skeletal molds. The organic carbon $\left(\mathrm{C}_{\text {org }}\right)$ content of the authigenic carbonate groundmass and cement was less than $0.4 \%$, whereas the sediment, especially at the Norfolk seep site, had higher $\% \mathrm{C}_{\text {org }}$ (Table 1). The shell carbonate was dominated by both aragonite and/or calcite with $\mathrm{CaCO}_{3}$ ranging between 95 to $97 \%$.

\subsection{Strontium isotopes}

The strontium isotope $\left({ }^{87} \mathrm{Sr} /{ }^{86} \mathrm{Sr}\right)$ compositions of the authigenic carbonates and mussel shells were investigated to constrain the fluid source and flow pathway for carbonate precipitation (Sample et al., 1993). ${ }^{87} \mathrm{Sr} /{ }^{86} \mathrm{Sr}$ ratios for the authigenic carbonates, mussel shells, and water 
samples ranged from 0.70915 to 0.70924 (Tables 1 and 2). The average authigenic carbonate $(\mathrm{n}=4)$ and mussel shell $(\mathrm{n}=2){ }^{87} \mathrm{Sr} /{ }^{86} \mathrm{Sr}$ ratios at both sites were equivalent, $0.70920 \pm 3 \times 10^{-5}$ and $0.70920 \pm 2 \times 10^{-5}$, respectively. In comparison, the average seawater $(\mathrm{n}=6){ }^{87} \mathrm{Sr} /{ }^{86} \mathrm{Sr}$ ratio was $0.70917 \pm 2 \times 10^{-5}$ but was not statistically different (Student T-test; $\mathrm{p}>0.05$ ) from the authigenic carbonate and shell samples.

\subsection{Stable carbon, oxygen, and sulfur isotopes}

At Norfolk, shells from both living and dead mussels yielded average $\delta^{13} \mathrm{C}$ values of $-2.59 \pm$ $1.68 \%$ o $(n=34)$ and $-7.10 \pm 3.20 \%(n=16)$, respectively, and an average $\delta^{18} \mathrm{O}$ value of $3.71 \pm$ $0.25 \%$ o $(\mathrm{n}=34)$ and $3.82 \pm 0.39 \%$ ( $\mathrm{n}=16)$, respectively (Table 2). No statistical difference (Student's t-test, $\mathrm{P}>0.05$ ) exists between shell $\delta^{18} \mathrm{O}$ values from dead and living specimens; however, shells from living mussels were significantly enriched in ${ }^{13} \mathrm{C}$ relative to shells from dead specimens (Student's t-test, $\mathrm{P}<0.05$ ). Only shells from live mussel specimens were analyzed from the Baltimore Canyon seep site and yielded average shell $\delta^{13} \mathrm{C}$ and $\delta^{18} \mathrm{O}$ values of and $-6.84 \pm 1.97 \%$ and $2.57 \pm 0.28 \%$ o $(\mathrm{n}=30)$, respectively. At both sites, the shell $\delta^{13} \mathrm{C}$ values were lighter relative to bottom water dissolved inorganic carbon (DIC) $\delta^{13} \mathrm{C}$ values $(0.90 \pm 0.05$; $\mathrm{n}=2$ ), but heavier relative to the Baltimore Canyon methane $\delta^{13} \mathrm{C}$ value (-68\%o; Pohlman et al., 2015). Compared to shells from Norfolk, mussel shell isotope values from Baltimore Canyon were heavier in $\delta^{13} \mathrm{C}$ and $\delta^{18} \mathrm{O}$ by $\sim 4 \%$ and $\sim 1 \%$, respectively. At both sites, shells $\delta^{18} \mathrm{O}$ were enriched in ${ }^{18} \mathrm{O}$ relative to ambient seawater, where bottom water $\delta^{18} \mathrm{O}$ values from Norfolk and Baltimore canyons were 0.34 and $0.53 \%$, respectively. 
Shell isotopic variability over the lifespan of an individual specimen was calculated as the standard deviation of 8 to 12 stable isotope values from material collected along a transect from the umbo to the ventral margin (Fig. S2). Individual lifespan variability ranged from 0.11 to $0.56 \%$ and 0.69 to $3.57 \%$ or shell $\delta^{18} \mathrm{O}$ and $\delta^{13} \mathrm{C}$ values $(\mathrm{n}=13)$, respectively. On average, the $\delta^{18} \mathrm{O}$ and $\delta^{13} \mathrm{C}$ variability over the mussel lifespan was 0.24 and $1.49 \%$, respectively. Lifespan variability represented less than $10 \%$ of the average shell $\delta^{18} \mathrm{O}$ signature at both sites, but up to $42 \%$ of the average shell $\delta^{13} \mathrm{C}$ signal at the Norfolk seep site and $21 \%$ at the Baltimore Canyon seep site. The mussel periostracum $\delta^{13} \mathrm{C}$ signature from samples collected at Norfolk seep field ranged from -70.66 to $-29.92 \%$ o $(n=40)$, with an average value of $-56.99 \pm 12.85 \%$ (Table 2 ). Mussel periostracum from Baltimore Canyon was not analyzed since sample preservation in ethyl alcohol precluded reliable $\delta^{13} \mathrm{C}$ results.

The average $\delta^{13} \mathrm{C}$ signature of the bulk authigenic carbonate from Norfolk and Baltimore canyons was $-45.51 \pm 1.66 \%$ o $(n=5)$ and $-48.43 \pm 1.02 \%$ o $(n=4)$, respectively. However, in comparison to the cement, the groundmass $\delta^{13} \mathrm{C}$ values were heavier by $1-3 \%$ (Table 1 ). The bulk $\delta^{18} \mathrm{O}$ values were similar, $3.80 \pm 0.05 \%$ o (Norfolk, $\mathrm{n}=5$ ) and $3.95 \pm 0.47 \%$ (Baltimore Canyon, $n=4)$ with $<1 \%$ difference between the groundmass and cement at both sites (Table 1). The authigenic carbonate $\delta^{18} \mathrm{O}$ values were heavier by $\sim 3 \%$ relative to bottom water $\delta^{18} \mathrm{O}$ values.

Sulfur $\left(\delta^{34} S\right)$ isotopes were analyzed from Bathymodiolus sp. gill tissues collected at each seep field. Gill $\delta^{34} \mathrm{~S}$ values ranged from -4.07 to $21.55 \%$ (Table 3 ), with no statistical difference between the sites (Student's t-test, $\mathrm{P}>0.05$ ); however, gill $\delta^{34} \mathrm{~S}$ values at Baltimore Canyon 
displayed a larger range compared to the Norfolk seep, from -4.07 to $18.13 \%$ o $(n=20)$ versus 8.65 to $21.55 \%$ o $(n=23)$. Periostracum $\delta^{34} \mathrm{~S}$ values from the Norfolk seep were similar to gill $\delta^{34} \mathrm{~S}$ values, ranging from 8.82 to $22.65 \%$, averaging $16.63 \pm 4.01 \%$ ( $=28)$. Seep sediment $\delta^{34} \mathrm{~S}$ values averaged 5.53 $\pm 2.16 \%$ o $(n=4)$ at Norfolk and $2.42 \pm 3.6 \%$ o $(n=5)$ at Baltimore Canyon (Table 3).

\subsection{Radiocarbon $\left({ }^{14} \mathrm{C}\right)$ analysis}

The $\Delta^{14} \mathrm{C}$ signatures of the authigenic carbonates were significantly depleted in ${ }^{14} \mathrm{C}$, ranging from $-959 \%$ to $-740 \%$ with corresponding ${ }^{14} \mathrm{C}$ ages of $25,570 \pm 210$ to $10,770 \pm 35{ }^{14} \mathrm{C}$ years (Table 4 ). The ${ }^{14} \mathrm{C}$ ages of mussel shells on the seabed were younger relative to the authigenic carbonate age. The ${ }^{14} \mathrm{C}$ age of the mussel shells derived from living specimens varied from $905 \pm 20$ to $1,935 \pm 20{ }^{14} \mathrm{C}$ years, and the average ${ }^{14} \mathrm{C}$ age of the mussel shells derived from dead specimens at Norfolk was $1,345 \pm 20{ }^{14} \mathrm{C}$ years (Table 4). There was no statistical difference (Student's T-test, $\mathrm{P}>0.05$ ) between shell from dead specimens that were pretreated with $10 \% \mathrm{HCl}$ and those left untreated (Table 4), yielding an average ${ }^{14} \mathrm{C}$ age of $1,180{ }^{14} \mathrm{C}$ years, indicating that secondary aragonite and calcite are negligible.

\subsection{U-Th age calculation}

Discrete subsamples of late-stage cavity-filling authigenic carbonate weighing between 4.1-17.2 mg were hand-drilled from two hand specimens collected from the Baltimore $(n=5)$ and Norfolk Canyon (n=5) sites (Fig. 4). These were analysed along with 9 detritus samples (5 from Norfolk and 4 from Baltimore Canyon) consisting of material loosely adhering to the outside surfaces of the hand specimens, and material recovered from the base of push cores collected within $2 \mathrm{~km}$ of 
the authigenic carbonates. Tabulated results are reported in Table 5. Authigenic carbonate cement samples contained 3.2 to $4.6 \mathrm{ppm} \mathrm{U}$, and 0.06 to $0.59 \mathrm{ppm} \mathrm{Th} .{ }^{230} \mathrm{Th} /{ }^{232} \mathrm{Th}$ activity ratios were between 2.2 and 8.6, clustering towards the lower end of the range reported from other occurrences of methane-related authigenic carbonates (e.g., Teichert et al. 2003; Bayon et al. 2009; Fig. S3 A). The implication is that the analysed authigenic carbonates incorporate detrital material, such as clay minerals, which carry ${ }^{232} \mathrm{Th}$, and an associated amount of initial ${ }^{230} \mathrm{Th}$. Since initial ${ }^{230} \mathrm{Th}$ is not related to the in-situ decay of ${ }^{234} \mathrm{U}$, a correction is required in order to calculate a robust carbonate precipitation age. The presence of initial ${ }^{230} \mathrm{Th}$ is typically addressed via (i) leaching techniques aimed at separating the carbonate and detrital components of a sample in order to calculate a two-point isochron age (e.g. Teichert et al., 2003; Berndt et al., 2014), or total dissolution of the samples, with detrital corrections based on either (ii) a theoretical detritus composition which assumes secular equilibrium in the ${ }^{238} \mathrm{U}$ decay chain, and $\mathrm{a}{ }^{232} \mathrm{Th} /{ }^{238} \mathrm{U}$ ratio linked to average continental crust composition (e.g. Aharon et al., 1997; Feng et al., 2010; Liebetrau et al., 2014), or (iii) a measured, site-specific detrital isotopic composition (e.g. Teichert et al., 2003; Bayon et al., 2009; 2015). Initial ${ }^{230} \mathrm{Th}$ in marine authigenic carbonates is likely to be a mixture of ${ }^{230} \mathrm{Th}$ incorporated within the detrital material and hydrogenous ${ }^{230} \mathrm{Th}$ scavenged onto grain surfaces from the decay of ${ }^{234} \mathrm{U}$ in the water column, with the impact of the latter increasing with water depth (Henderson and Anderson, 2003). Consequently, site-specific corrections are likely to be more appropriate, particularly for samples collected at depths greater than a few hundred meters. The impact of excess ${ }^{230} \mathrm{Th}$ scavenged from seawater is illustrated by the measured $\left({ }^{230} \mathrm{Th} /{ }^{238} \mathrm{U}\right)$ of the five detritus samples from the Norfolk Canyon site (depth of $\sim 1600 \mathrm{~m}$ ), which range from 1.7 to 2.1 (Table 5), and are significantly higher than the secular equilibrium value of 1 . Conversely $\left({ }^{230} \mathrm{Th} /{ }^{238} \mathrm{U}\right)$ values from the shallower Baltimore Canyon site 
(depth $\sim 385 \mathrm{~m}$ ) are, as expected, lower (1.29-1.46) but still in excess of secular equilibrium. Details of the average detrital U and Th compositions used to calculate corrected U-Th dates at Baltimore Canyon and Norfolk Canyon are provided in the supplementary material.

The U-Th ages from the Norfolk seeps, corrected for initial detrital and hydrogenous ${ }^{230} \mathrm{Th}$, range from $1.0 \pm 0.7 \mathrm{ka}$ to $3.3 \pm 1.3 \mathrm{ka}$ (Table 5). In comparison, the corrected U-Th ages of the Baltimore Canyon authigenic carbonate were older, ranging from $14.7 \pm 0.6$ ka to $15.7 \pm 1.6 \mathrm{ka}$ (Table 5). Modelled initial $\left({ }^{234} \mathrm{U} /{ }^{238} \mathrm{U}\right)_{\mathrm{i}}$ values are statistically equivalent to the mean modern seawater $\left({ }^{234} \mathrm{U} /{ }^{238} \mathrm{U}\right)$ of 1.1466 (Robinson et al., 2004; Fig. S3 B), meaning that $\mathrm{U}$ incorporated in the authigenic carbonates was sourced from seawater, rather than pore waters, which would be comparatively enriched in ${ }^{234} \mathrm{U}$ (Henderson et al., 1999).

\section{Discussion}

\subsection{Authigenic carbonate formation}

The aragonite-dominated authigenic carbonates form pavements and/or irregular blocky buildups on the seafloor. The carbonates consist of bioclasts, organic matter, and angular clasts of terrigenous origin. While the contemporary Baltimore Canyon does not connect with a river system, rivers delivered a significant volume of sediment to the submarine canyons incising the shelf during Pleistocene sea-level lowstands (e.g., Forde et al. 1981). The fluvial influence on the canyons is observed in both the geomorphic features and grain size, where coarse to medium grained, shelly terrigenous sands are observed adjacent to the canyon heads (Obelcz et al. 2014). The similarity between neodymium isotope $\left({ }^{143} \mathrm{Nd} /{ }^{144} \mathrm{Nd}\right)$ values from Baltimore Canyon surface sediment (0.51208; Prouty et al., 2015) and Hudson River sediment (0.51206; Goldstein and Jacobsen 1987) highlights past connectivity with proximal fluvial sources. 
The authigenic carbonate texture may result from in-situ brecciation of weakly consolidated sediment, possibly triggered by seismic and venting-induced disturbances, such as rapid sedimentation related to episodic and rapid release of trapped fluids or gases (Matsumoto 1990). Fractures cross cutting multiple generations of aragonite precipitate in the Baltimore Canyon authigenic carbonate (Fig. 4) may signify past disturbance events. The dominance of aragonite at both seep sites suggests precipitation at or close to the seafloor (see review in Suess 2014), where sufficiently high sulfate concentrations inhibit high-Mg calcite crystallization (e.g., Bohrmann et al. 1998). This interpretation is consistent with carbonate ${ }^{87} \mathrm{Sr} /{ }^{86} \mathrm{Sr}$ and $\delta^{234} \mathrm{U}$ isotope results that indicate precipitation from seawater-derived fluids (e.g., Naehr et al. 2007), rather than deep-seated formation waters that are less radiogenic than modern seawater.

\subsection{Anaerobic oxidation of methane}

The main driver of authigenic carbonate precipitation at or near the sediment interface is anaerobic oxidation of methane (AOM) via sulfate reduction $\left(\mathrm{CH}_{4}+\mathrm{SO}_{4}{ }^{2-} \rightarrow \mathrm{HCO}_{3}{ }^{-}+\mathrm{HS}^{-}\right.$ $+\mathrm{H}_{2} \mathrm{O}$ ). This reaction drives an increase in pore water alkalinity by the production of biocarbonate $\left(\mathrm{HCO}_{3}^{-}\right)$and favors carbonate precipitation. Carbonate precipitation from methanogenesis can also occur deeper in the sediment column (e.g., Orphan et al. 2004; Gieskes et al. 2005) and is typically characterized by carbonate $\delta^{13} \mathrm{C}$ values > $-40 \%$ (Aharon et al. 1997). However, authigenic carbonate $\delta^{13} \mathrm{C}$ values from Norfolk and Baltimore canyons are lighter (-45 to $-48 \%$ ), in agreement with $\delta^{13} \mathrm{C}$ values at cold seep sites where microbial $\mathrm{AOM}$ is the dominant driver of authigenic aragonite precipitation. The heavier $\delta^{13} \mathrm{C}$ values of the authigenic carbonates compared to methane represent the incorporation of seawater DIC that is relatively enriched in ${ }^{13} \mathrm{C}$. Results of a two end-member $\delta^{13} \mathrm{C}$ mixing model yield a contribution from 
methane-derived carbon of $\sim 70 \%$, with the remaining $\sim 30 \%$ attributed to seawater DIC-derived carbon precipitated near the sediment-water interface. Furthermore, $\delta^{13} \mathrm{C}$ values of $\mathrm{AOM}$-related lipids extracted from the authigenic carbonates were strongly depleted in ${ }^{13} \mathrm{C}$, (i.e., archaeol: 74.3\%o; Campbell et al., 2015), confirming the dominance of microbial methane as the dominant carbon source for the Archaea. The authigenic carbonate $\delta^{13} \mathrm{C}$ and $\delta^{18} \mathrm{O}$ values are also consistent with Group I carbonates that typify carbonate precipitation of microbial origin within the uppermost few centimeters below the sediment-water interface (Joseph et al. 2013).

In addition to AOM, sulfate reduction is also a dominant process that occurs in methane-rich sediments, resulting in sulfur fractionation in the pore water and sediment. Sulfate reduction may therefore explain the light surface sediment $\delta^{34} \mathrm{~S}$ values (from -2.62 to $8.20 \%$; Table 3 ) relative to seawater sulfate $(+20 \%$; Heyl et al. 2007). The resulting hydrogen sulfide can then be used to support the metabolic processes of surrounding chemosynthetic communities. For example, Van Dover et al. (2003) reported that the mussel B. heckerae collected from Blake Ridge derive up to $25 \%$ of their organic sulfur from sulfide. Using a two end-member mixing model with a $\mathrm{H}_{2} \mathrm{~S} \delta^{34} \mathrm{~S}$ value of $-10 \%$, and the average Bathymodiolus sp. gill $\delta^{34} \mathrm{~S}$ values from each seep site, the reliance on $\mathrm{H}_{2} \mathrm{~S}$ as an energy source at Norfolk and Baltimore canyon seep fields was estimated at $16 \%$ and $14 \%$, respectively. However, variable gill $\delta^{34} \mathrm{~S}$ values indicate uptake of up to $80 \%$ of $\mathrm{H}_{2} \mathrm{~S}$ (i.e., gill $\delta^{34} \mathrm{~S}$ value of $-4.07 \%$ at the Baltimore Canyon Seep site), suggesting free-living and/or symbiotic thiotrophic bacteria may play a nutritional role at the base of the food web (Yamanaka et al. 2003). As an alternative to mussel tissue isotopic studies, the mussel shell periostracum derived from both living and dead specimens represents a valuable source of information about the seep environment. The similarity between the periostracum and 
mussel gill $\delta^{34} \mathrm{~S}$ values from Norfolk suggests a high degree of nutrient flow between the soft tissue, allowing for greater fidelity in using periostracum isotopic ratios in place of respirable tissues of living specimens. This is particularly essential when mussel tissue is not available, such as with archived specimens or those at quiescent vent sites.

\subsection{Estimation of fluid composition and age}

The composition of the seeping fluids can also be characterized by the mussel shell $\delta^{13} \mathrm{C}$ values, with differences between the living and dead specimens reflecting changes in the flux of methane in the past, or possibly a change in the composition of the seeping fluids. At both sites, the shell carbonate and periostracum $\delta^{13} \mathrm{C}$ values were lighter relative to bottom water DIC $\delta^{13} \mathrm{C}$ values (Table 2). This difference suggests an additional carbon source for shell calcification, and illustrates the decoupling between calcification and metabolic pathway (Aharon et al. 1997). The light periostracum $\delta^{13} \mathrm{C}$ values (-57\%; Table 2) agree with previous work concluding that mussel shell periostracum originates from dietary sources, and is an alternative to soft tissue for trophic studies (Geist et al. 2005). Assuming a regional methane $\delta^{13} \mathrm{C}$ value of $-68 \%$ (Pohlman et al., 2015), the average percent contribution of methane to shell calcification was estimated at $11 \%$ at Baltimore Canyon and $5 \%$ at Norfolk. However, shell $\delta^{13} \mathrm{C}$ values from dead specimens collected at Norfolk indicate a temporal shift in seepage activity and/or composition of seeping fluids. Specifically, a reduction in $\delta^{13} \mathrm{C}$ values of up to $17 \%$ observed in the dead specimens is equivalent to a $\sim 25 \%$ increase in methane contribution to shell calcification. Comparison of relative ${ }^{14} \mathrm{C}$-derived ages from the dead and live specimens suggests this change could have occurred within a few centuries (<500 years) (Table 4$)$. 
Carbonate shell $\delta^{13} \mathrm{C}$ variability also has the potential to record environmental changes such as changes in fluid source, as well as fluid-venting activity over the lifespan of the mussels (e.g., Lietard and Pierre 2008). Although the precise chronology of the variability is unknown because of the difficulty in dating the specimens, estimates of ages of B. brevior and B. thermophiles range from 18 to more than 25 years (Schöne and Giere 2005). Therefore, lifespan $\delta^{13} \mathrm{C}$ variability reported above may be related to changes in methane flow within several decades. The spatial distribution of living and dead mussels may also imply changing fluid composition or flux rates, as suggested by Van Dover et al. (2003) from HOV dives on the Blake Ridge Diapir.

The shell carbonate $\delta^{18} \mathrm{O}$ isotopic signature at Norfolk overlap with both Bathymodiolus and Calyptogena shell samples from other cold seeps (Lietard and Pierre 2008). In comparison, Baltimore Canyon shell $\delta^{18} \mathrm{O}$ values are lighter, reflecting warmer in-situ temperatures $\left(\sim 9^{\circ} \mathrm{C}\right)$ relative to the deeper, colder in-situ temperatures $\left(\sim 4^{\circ} \mathrm{C}\right)$ at Norfolk. Using bottom water $\delta^{18} \mathrm{O}$ values from Baltimore and Norfolk canyons, the predicted carbonate $\delta^{18} \mathrm{O}$ value precipitated at equilibrium yields heavier carbonate $\delta^{18} \mathrm{O}$ values relative to measured shell values from Baltimore and Norfolk by 0.68 and $0.42 \%$ respectively. Therefore, there is evidence of isotopic disequilibrium, indicating the influence of ${ }^{18} \mathrm{O}$-poor water and/or warmer seeping fluids (e.g. Lietard and Pierre 2008). As a result, the predicted seawater temperatures using an aragonite paleotemperature equation of Grossman and $\mathrm{Ku}$ (1986) are warmer by $1-3^{\circ} \mathrm{C}$ compared to contemporary in-situ temperatures, a difference at least three times greater than the $\delta^{18} \mathrm{O}$-derived temperature analytical uncertainty of $0.28^{\circ} \mathrm{C}$. 
The influence of methane is also captured in the light carbonate $\Delta^{14} \mathrm{C}$ values and relatively old ${ }^{14} \mathrm{C}$-derived ages of mussel shells from living specimens. Seawater samples collected near the Norfolk seep field yield an average $\mathrm{DI}^{14} \mathrm{C}$ value of $-24.17 \pm 0.6 \%$, consistent with seawater $\Delta{ }^{14} \mathrm{C}$ values from below the mixed layer depth in Norfolk Canyon. In contrast, the average mussel shell $\Delta{ }^{14} \mathrm{C}$ value from living specimens from the Norfolk seep field is $-115 \pm 3 \%$. Assuming a methane $\Delta^{14} \mathrm{C}$ signature of $-880 \%$ o $\left(<0.12 \mathrm{pMC}\right.$; Pohlman et al. 2009) and a DIC $\Delta^{14} \mathrm{C}$ signature of $-24 \%$ (this study), $\sim 10 \%$ of the carbon signature for shell calcification is derived from fossil carbon. As a result, the contribution from fossil carbon can yield a false ${ }^{14} \mathrm{C}$ carbonate age (e.g., Aharon et al. 1997). The dilution from fossil carbon may result in over prediction of ${ }^{14} \mathrm{C}$-derived ages by 5 to $11 \%$.

Owing to this incorporation of fossil carbon, we expect a disparity between the ${ }^{14} \mathrm{C}$-derived age of the authigenic carbonates and the independently derived U-Th age. The average $\Delta^{14} \mathrm{C}$ signatures of the authigenic carbonates at both sites are significantly depleted in ${ }^{14} \mathrm{C}$, with values ranging from $-894 \%$ to $-878 \%$ and corresponding ${ }^{14} \mathrm{C}$ ages ranging from 17.99 to $19.35 \mathrm{ka}$. In comparison, average U-Th ages from the Norfolk and Baltimore canyon seep sites were 1.0-3.3 ka and 14.7-15.7 ka, respectively. Thus, the disparity between the ${ }^{14} \mathrm{C}$ and $\mathrm{U}-\mathrm{Th}$ derived ages is a few thousand years at the Baltimore Canyon seep but at least $13 \mathrm{ka}$ at the deepwater Norfolk seep. The differences between the ${ }^{14} \mathrm{C}$ and U-Th ages are probably a complex function of absolute age of the authigenic carbonates, methane flux, and the ${ }^{14} \mathrm{C}$ signature of the source methane, and the results may imply greater incorporation of fossil carbon in the authigenic carbonates at Norfolk Seep. 


\subsection{Formation model and paleoenvironment}

The U-Th ages from methane derived authigenic carbonates indicate that hydrocarbon seepage related to the formation of those carbonates occurred at the Baltimore Canyon seep field toward the end of the Late Pleistocene, and was more recent (Holocene) at the Norfolk seep field. These are the first absolute dates for the timing of hydrocarbon seepage along the US Atlantic margin, and although the limited nature (single samples at two sites) these ages are supported by additional U-Th dating conducted on more recently obtained authigenic carbonate samples along the US Atlantic margin (Condon et al., 2015). Nonetheless, the origin of seeps and gas expulsion geomorphic features (e.g., pockmarks and "gas blowouts") along the US Atlantic Margin remains uncertain.

The occurrence of gas seeps and pockmarks associated with fluid expulsion at depths less than $500 \mathrm{~m}$, which are outside the methane hydrate stability field, may have a microbial origin from in-situ bacterial decay of organic matter or updip migration of gases produced by the same process or released from methane hydrate dissociation at greater water depths on the upper slope (Skarke et al. 2014). Such expulsion may also have a thermogenic origin at depth (Hill et al. 2004; Newman et al. 2008; Brothers et al. 2014). However, the geochemical analyses presented here yield carbonate $\delta^{13} \mathrm{C}$ values $<-40 \%$. When coupled with observations by Pohlman et al. (2015) of $-68 \%$ in the bottom waters, a thermogenic origin for the methane is precluded. This agrees with earlier work by Newman et al. (2008) that demonstrated the microbial origin of pore fluid DIC $\delta^{13} \mathrm{C}$ values along the US mid-Atlantic shelf break. Hill et al. (2004) argued that microbial gas flowing updip from dissociating gas hydrates is responsible for the distribution of gas blowouts in the region, and Skarke et al (2014) make the same argument for the distribution 
of hundreds of seeps on the continental slope updip of the present-day hydrate stability limit, particularly on the mid-Atlantic part of the margin. Recent multi-channel seismic profiles on the upper continental slope below the Baltimore Canyon seep field do not reveal clear evidence for strata that could be laterally channeling gas updip into the seeps (Ruppel et al., 2015b), but these observations are equivocal.

An alternate explanation for the presence of the Baltimore Canyon seeps at $\sim 400 \mathrm{~m}$ water depth is that overpressures have accumulated within thick, rapidly deposited Pleistocene sediments, leading to vertical fluid and gas expulsion (Brothers et al. 2014). Studies on passive margins offshore Europe and Asia have also advanced this explanation for focused fluid flow in areas of high sedimentation rates under excess pore pressure (Berndt 2005). This interpretation is consistent with the non-aquifer model of Dugan and Flemings (2002), where rapid sediment loading during the Pleistocene sea-level lowstand created overpressure gradients, forcing fluids to migrate upward and outward toward the seafloor. During the Pleistocene, significant volumes of sediment were delivered to the outer shelf, with much of it transported directly into shelfsourced canyons and then offshore to deep-sea fans (e.g., Poag 1992). The fluvial influence on the canyons is observed in both the geomorphic features and grain size, where coarse to medium grained, shelly terrigenous sands are observed adjacent to the canyon heads (Obelcz et al. 2014). The Mid-Atlantic region is also marked by a seaward thickening wedge of shelf edge delta deposits (200-400 m thick) (Hill et al., 2004; D. Brothers et al., 2013). Along the New Jersey continental slope for example, sedimentation rates rose sharply during Pleistocene sea-level lowstand (Dugan and Flemings, 2002), with rates as high as $353 \mathrm{~cm} \mathrm{kyr}^{-1}$ (McHugh and Olson, 2002). The age of the Baltimore Canyon authigenic carbonate further supports a link between 
rapid loading by organic-rich sediment during the Pleistocene sea-level lowstand and subsequent fluid flow from overpressure. Such overpressures may also contribute to pervasive slope instability on this part of the Mid-Atlantic margin (ten Brink et al., 2014).

Our analysis (Fig. 5) shows that the Baltimore seep field would have been outside the methane hydrate stability field even between $14.7 \pm 0.6$ ka to $15.7 \pm 1.6 \mathrm{ka}$. The ensuing Late Pleistocene to Holocene sea-level rise increased hydrostatic pressure, which could move the seep field closer to the hydrate stability condition under isothermal conditions. However, dramatic bottom water warming between the presumed cold Late Pleistocene temperature and the $\sim 9^{\circ} \mathrm{C}$ observed in 2013 from in-situ temperature measurements overwhelms the impact of increased pressure. The Baltimore Canyon seep field may now or in the past have emitted migrated methane that was released by gas hydrate dissociation at greater water depths; however in-situ gas hydrate dissociation is clearly ruled out as the source of methane emissions. This regime contrasts with the hydrate-controlled methane venting off Svalbard, where seasonal fluctuations in bottom water temperatures cause variable gas hydrate dissociation at a depth between 380 to $400 \mathrm{~m}$ (Berndt et al., 2014).

The driving mechanism for methane venting the Norfolk seep field $(\sim 1600 \mathrm{~m})$ is more difficult to explain since the seep is well inside the gas hydrate stability zone and there is no underlying salt diapir. Skarke et al. (2014) postulated that the Norfolk seep field is fed by gas flowing through fractured Eocene rock, but a clear triggering mechanism that could explain seepage consistent mid-Holocene U-Th date of the authigenic carbonates is lacking. Recent highresolution seismic imaging by the USGS shows fractures channeling methane to the seep sites 
from hundreds of meters below the seafloor (Ruppel et al., 2015a). Despite the inferred deep source of some of the methane, it is notable that the $\delta^{13} \mathrm{C}$ data still support an entirely microbial origin for the gas. There is evidence at both sites of upward flux of methane that is isotopically similar between the sites with respect to carbon, most likely linked to long-term accumulation, compaction, and over-pressuring of organic-rich sediment. This can occur when the intense methane fluxes move the sulfate-methane transition zone (SMTZ) very close to the seafloor (Orcutt et al., 2011).

\subsection{Relationship to Global Setting}

A variety of driving mechanisms has been proposed to explain methane venting at cold seeps, including hydrological and tidal pumping, warming of bottom water (Suess 2014), excess pore pressure in areas of high sedimentation along the passive margins of Europe and Africa (Berndt 2005), seismic activity (e.g., Fischer et al., 2013), and links to sea-level lowstands (e.g., Teichert et al., 2003; Feng et al., 2010; Liebetrau et al., 2010). In many of these cases, a major mechanism for methane release is a change in hydrostatic pressure and/or temperature, and subsequent hydrate dissociation, as in the case of the South China Sea (Han et al., 2014) and Svalbard (Westbrook et al., 2009; Berndt et al., 2014). Even with the assumption of very cold bottom water temperatures, the Baltimore seep field would have been outside the methane hydrate stability field at $\sim 15 \mathrm{ka}$ (Fig. 5), meaning that in-situ gas hydrate dissociation cannot have ever contributed to methane emissions there since the Late Pleistocene. Despite observations of numerous landslide scars in the Baltimore Canyon landslide zone (ten Brink et al. 2014), ages that could constrain the timing of slide events are are not available close to the seep site. The ages farther downslope at the base of hemipelagic sediment overlying the youngest mass transport deposit range between $5200 \pm 150$ and 10,080 yr BP (Embley, 1980). While these 
dates are several thousand years younger than the age of the authigenic carbonate samples analyzed from the Baltimore Canyon seep field site, the slide material that was dated is probably not related to sediments originally at the top of the ridge where the seep field is located. For now, we can only postulate that other passive margins with similar depositional regimes similar to that of the northern US Atlantic margin may also be the loci of widespread and as-yet undiscovered seepage that can be traced to similar mechanisms of overpressure accumulation and eventual fluid expulsion, possibly with a slide-related connection.

\section{Conclusion}

The geochemistry, mineralogy, and petrology of authigenic carbonates and mussel shells collected from two seep sites along the mid-Atlantic portion of the USAM in a newly-discovered seep province provide the first direct information about methane sources, the processes driving carbonate precipitation and chemosynthetic processes, and the nature of fluid-rock interaction. Taken together, the $\delta^{234} \mathrm{U},{ }^{87} \mathrm{Sr} /{ }^{86} \mathrm{Sr}, \delta^{13} \mathrm{C}$ and $\Delta^{14} \mathrm{C}$ values support shallow precipitation of aragonite driven by $\mathrm{AOM}$ and at equilibrium with seawater. At the deepwater Norfolk seep, comparison of shell $\delta^{13} \mathrm{C}$ values from dead and living specimens indicates a temporal shift in seepage activity and/or composition of seeping fluids. Comparison between shell $\delta^{13} \mathrm{C}$ values of living versus dead specimens from Norfolk suggests a $\sim 25 \%$ increase in methane contribution within several centuries. In addition, changes in shell $\delta^{13} \mathrm{C}$ values during growth may be related to changes in methane flow throughout the organisms' lifespan $(<25$ years $)$. The range of mussel gill and periostracum $\delta^{34} \mathrm{~S}$ values from both sites suggests an admixture of sulfur sources, hydrogen sulfide $\left(\mathrm{H}_{2} \mathrm{~S}\right)$ and seawater sulfate $\left(\mathrm{SO}_{4}\right)$, with the former sourced from sulfate reduction during AOM. Lighter mussel shell $\Delta{ }^{14} \mathrm{C}$ values highlight dilution of the ${ }^{14} \mathrm{C}$ pool with 
fossil carbon. As a result, authigenic carbonate ${ }^{14} \mathrm{C}$ - and U-Th-derived ages are discordant.

According to U-Th ages, methane seepage is thought to have occurred at the uppermost slope Baltimore Canyon seep field toward the end of the Pleistocene $(14.7 \pm 0.6 \mathrm{ka}$ to $15.7 \pm 1.6 \mathrm{ka})$ and between $1.0 \pm 0.7 \mathrm{ka}$ to $3.3 \pm 0.1 .3 \mathrm{ka}$ at the deepwater Norfolk seep field. Fluid flow from the thick pile of overpressured Pleistocene sediments deposited at the sea-level lowstand is the most likely mechanism to explain sustained methane venting at Baltimore Canyon, whereas venting fluids at the Norfolk seeps, which are located well within the GHSZ, can be explained by flow through fractured strata (Skarke et al. 2014; Ruppel et al., 2015a). At neither seep field does the carbonate geochemistry support deep-sourced fluid of thermogenic origin. Instead, the isotope and mineralogy of the carbonates indicate that microbial degradation of sedimentary organic matter is the common source of widespread methane both outside (Baltimore Canyon) and well within (Norfolk seep) the GHSZ. Results from this geochemical study, coupled with the geophysical data of Skarke et al (2014) showing the distribution of seeps along the USAM, highlights the potential role of the sedimentary framework in widespread venting at upper slope locations updip of the current limit of gas hydrate stability. We postulate that high sedimentation rate passive margins dominated by siliciclastic deposition due to glacial and fluvial processes may have accumulated overpressures and produced episodes of fluid expulsion particularly during Late Pleistocene lowstands. This implies that undiscovered methane seep provinces may be widespread on upper continental slopes, which would have implications for carbon cycling from the seafloor to overlying ocean-atmosphere system.

Acknowledgments Funding for this project (sponsored by the National Oceanographic Partnership Program) included USGS Terrestrial, Freshwater, and Marine Environments Program through the Outer Continental shelf study, Coastal and Marine Geology Program, and 
the Bureau of Ocean Energy Management (BOEM) contract number M10PC00100 (contracted to CSA Ocean Sciences, Inc.). C.R. was supported by USGS-DOE Interagency Agreements DEFE000291 and 0023495. We thank Greg Boland (BOEM) and Stephen Viada (CSA) for support during the development of the overall project. We thank the crews of the NOAA ships Nancy Foster and Ronald H. Brown, and Kraken II and Jason II ROVs, provided by the NOAA Office of Ocean Exploration and Research. We thank D. Brothers, and J. Kluesner (USGS) for helpful discussions, K. Davis (Texas A\&M), B. Harlow (WSU), I. Aiello (MLML), S. Griffin (UCI), and P. Campbell-Swarzenski, J. Fitzpatrick, and J. Hein (USGS) for analytical assistance, and J. Bourque and J. McClain Counts (USGS) and M. Rhode (UNCW) for field and lab assistance. J. Hein (USGS) and two anonymous reviewers provide valuable input. Any use of trade, product, or firm names is for descriptive purposes only and does not imply endorsement by the U.S. Government.

\section{Figure Captions}

\section{Figure 1}

Location map showing the Norfolk and Baltimore Canyon seep fields (green circles) relative to the major shelf-break canyons (Norfolk, Washington, and Baltimore). The blue triangle outlines the study area for the multi-disciplinary "Atlantic Deepwater Canyons" study.

\section{Figure 2}

(A) Baltimore Canyon, with the seep field located on the southern promontory overlooking the canyon. The green circle denotes the seep that was sampled for mussel shells and authigenic 
carbonates within the seep field. (B) Close-up view of shaded relief at the Baltimore Canyon seep field, with bathymetric contours at $100 \mathrm{~m}$ spacing. The green circle denotes the seep that is the focus of this paper. Red and orange circles are seeps from the Skarke et al. (2014) database and from USGS water-column imaging surveys in April 2015, respectively. Some of the orange and red seeps may correspond to the same location within the resolution of the data. Yellow symbols are pockmarks mapped by Brothers et al. (2014). (C) Left: In-situ photo of deep-sea mussel field of Bathymodiolus sp. Right: In-situ photo of deep-sea Cusk fish, Brosme brosme, beneath authigenic pavement in soft substrate with low live mussel cover (D) Target strength calculated from water column imagery collected with a Simrad EK60 using a $38 \mathrm{kHz}$ transducer during USGS surveys across the seep field in September 2015. The current deflects the plumes slightly southeast in the water column. The analysis used the approach and software described in Veloso et al. (2015).

\section{Figure 3.}

(A) Norfolk deep seep field, showing the locations of seeps in the Skarke et al. (2014) database (red circles) and the sampled seep for authigenic carbonate and mussels as a green circle. (B) Close-up of the Norfolk seep field, using the same key as in (A). (C) NOAA image of the plumes emanating from the seep field in 2013, with the seep sampled for this paper indicated in yellow. (D) Left: In-situ photo of dense deep-sea mussel field of live Bathymodiolus sp. on irregular blocky build-up on the seafloor. Right: In-situ photos of live Bathymodiolus sp. at active seep site with visible bubble stream.

\section{Figure 4}


Photographic and petrographic thin section images (plane polarized light; 40x) of the authigenic carbonates sampled at the Norfolk seep site (dive NF-2012-14) and Baltimore Canyon seep site (dive RB-2013-682). Infilling of voids by acicular aragonite, detrital grains, organic matter, and bioclasts are noted in the matrix-supported clay to silt-size aragonite-dominated breccia. Locations of sampling sites for U-Th dates (red squares) and radiocarbon (yellow squares) are shown for their respective locations and corresponding sample number from Tables 4 and 5.

\section{Figure 5}

The evolution of Baltimore Canyon (squares) and Norfolk (circles) seeps in depth-temperature (P-T) space relative to the methane hydrate stability field calculated with seawater salinity. Closed symbols are present-day depth and temperature, and open symbols denote estimated conditions at $15.1 \pm 1.6 \mathrm{ka}$ and $3 \pm 1 \mathrm{ka}$, respectively.

\section{References}

Aharon P, Schwarcz HP, Roberts HH (1997) Radiometric dating of submarine hydrocarbon seeps in the Gulf of Mexico. Geol Soc Am Bull 109:568-579

Bayon G, Henderson GM, Bohn M (2009) U-Th stratigraphy of a cold seep carbonate crust. Chem Geol 260:47-56

Bayon G, Henderson GM, Etoubleau J, Caprais J-C, Ruffine L, Marsset T, Dennielou B, Cauquil E, Voisset M, Sultan N (2015) U-Th isotope constraints on gas hydrate and pockmark dynamics at the Niger delta margin. Mar Geol 370:87-98

Berndt C (2005) Focused fluid flow in passive continental margins. Phil. Trans. R. Soc. A s 363:2855-2871

Berndt C, Feseker T, Treude T, Krastel S, Liebetrau V, Niemann H, Bertics VJ, Dumke I, Dünnbier K, Ferré B, Graves C, Gross F, Hissmann K, Hühnerbach V, Krause S, Lieser K, Schauer J, Steinle L (2014) Temporal Constraints on Hydrate-Controlled Methane Seepage off Svalbard. Science 343:284-287

Boetius A, Wenzhöfer F (2013) Seafloor oxygen consumption fuelled by methane from cold seeps. Nature Geosci 6:725-734

Bohrmann G, Greinert J, Suess E, Torres M (1998) Authigenic carbonates from the Cascadia subduction zone and their relation to gas hydrate stability. Geology 26:647-650

Brothers LL, Van Dover CL, German CR, Kaiser CL, Yoerger DR, Ruppel CD, Lobecker E, Skarke AD, Wagner JKS (2013) Evidence for extensive methane venting on the southeastern U.S. Atlantic margin. Geology 41:807810

Brothers DS, Luttrell KM, Chaytor JD (2013) Sea-level-induced seismicity and submarine landslide occurrence. Geology 41:979-982 
Brothers DS, Ruppel C, Kluesner JW, Brink US, Chaytor JD, Hill JC, Andrews BD, Flores C (2014) Seabed fluid expulsion along the upper slope and outer shelf of the US Atlantic continental margin. Geophys Res Lett 41:96101

Campbell KA (2006) Hydrocarbon seep and hydrothermal vent paleoenvironments and paleontology: Past developments and future research directions. Palaeogeogr. Palaeoclimatol. Palaeoecol. 232:362-407

Campbell PL, Prouty NG, Demopoulos, AWD, Roark, EB, Coykendall (2015) Lipid biomarkers and their specific carbon isotopic composition from cold seep community authigenic carbonates and sediments from the MidAtlantic Norfolk and Baltimore Canyons. Fall Meeting Amer. Geophys. Union, OS33A-2015.

Cheng H, Lawrence Edwards R, Shen C-C, Polyak VJ, Asmerom Y, Woodhead J, Hellstrom J, Wang Y, Kong X, Spötl C, Wang X, Calvin Alexander Jr E (2013) Improvements in ${ }^{230} \mathrm{Th}$ dating, ${ }^{230} \mathrm{Th}$ and ${ }^{234} \mathrm{U}$ half-life values, and U-Th isotopic measurements by multi-collector inductively coupled plasma mass spectrometry. Earth Planet Sci Lett 371-372:82-91

Condon D, Sahy D, Ruppel C, Prouty N, Noble S, Team SP (2015) Tempo and longevity of methane efflux along the US Atlantic margin. A Fall Meeting Amer. Geophys. Union, OS31B-07.

Dugan B, Flemings PB (2000) Overpressure and fluid flow in the New Jersey continental slope: implications for slope failure and cold seeps. Science, 289, 288-9

Dugan B, Flemings PB (2002) Fluid flow and stability of the US continental slope offshore New Jersey from the Pleistocene to the present. Geofluids 2:137-146

Duperron S, Guezi H, Gaudron SM, Pop Ristova P, Wenzhöfer F, Boetius A (2011) Relative abundances of methane- and sulphur- oxidising symbionts in the gills of a cold seep mussel and link to their potential energy sources. Geobiology 9:481-491

Embley RW (1980) The role of mass transport in the distribution and character of deep- ocean sediments with special reference to the North Atlantic. Marine Geology 38, 23-50.

Feng D, Roberts HH, Cheng H, Peckmann J, Bohrmann G, Lawrence Edwards R, Chen D (2010) U/Th dating of cold-seep carbonates: An initial comparison. Deep Sea Research Part II: Topical Studies in Oceanography 57:2055-2060

Fischer D, Mogollón JM, Strasser M, Pape T, Bohrmann G, Fekete N, Spiess V, Kasten S. (2013) Subduction zone earthquake as potential trigger of submarine hydrocarbon seepage. Nature Geoscience. 1;6(8):647-51

.Forde EB, Stanley DJ, Sawyer WB, Slagle KJ (1981) Sediment transport in Washington and Norfolk submarine canyons. Appl Ocean Res 3:59-62

Geist J, Auerswald K, Boom A (2005) Stable carbon isotopes in freshwater mussel shells: Environmental record or marker for metabolic activity? Geochim Cosmochim Acta 69:3545-3554

Gieskes J, Mahn C, Day S, Martin JB, Greinert J, Rathburn T, McAdoo B (2005) A study of the chemistry of pore fluids and authigenic carbonates in methane seep environments: Kodiak Trench, Hydrate Ridge, Monterey Bay, and Eel River Basin. Chem Geol 220:329-345

Goldstein SJ, Jacobsen SB (1987) The Nd and Sr isotopic systematics of river-water dissolved material: implications for the sources of Nd and $\mathrm{Sr}$ in seawater. Chem. Geol. (Isot. Geosci. Sect.) 66:245-272

Grossman E, Ku TL (1986) Oxygen and carbon isotope fractionation in biogenic aragonite: Temperature effects. Isot Geosci 59:59-74

Han X, Suess E, Liebetrau V, Eisenhauer A, Huang Y (2014) Past methane release events and environmental conditions at the upper continental slope of the South China Sea: constraints by seep carbonates. Int. J. Earth Sci. 103:1873-1887

Henderson GM, Anderson RF (2003) The U-series toolbox for paleoceanography. In Bourdon B, Henderson GM, Lundstrom CC, Turner SP (eds) Uranium Series Geochemistry, Rev. Mineral. Geochem, 52:493-531

Henderson GM, Slowey NC, Haddad GA (1999) Fluid flow through carbonate platforms: constraints from 234U/238U and Cl- in Bahamas pore waters. Earth Planet. Sci. Lett. 169:99-111

Heyl TP, Gilhooly WP, Chambers RM, Gilchrist GW, Macko SA, Ruppel CD, Van Dover CL (2007) Characteristics of vesicomyid clams and their environment at the Blake Ridge cold seep, South Carolina, USA. Mar Ecol Prog Ser 339:169-184

Hill JC, Driscoll NW, Weissel JK, Goff JA (2004) Large- scale elongated gas blowouts along the US Atlantic margin. J. Geophys. Res., 109, B09101, doi:10.1029/2004JB002969.

Holden NE (1990) Total half-lives for selected nuclides. Pure Appl Chem 62(5):941-958

Hornbach MJ, Ruppel C, Saffer DM, Van Dover CL, Holbrook WS (2005) Coupled geophysical constraints on heat flow and fluid flux at a salt diapir. Geophys Res Lett 32(24) doi: 10.1029/2005GL024862

Jaffrey A, Flynn K, Glendenin L, Bentley W, Essling A (1971) Precision measurement of half-lives and specific activities of ${ }^{235} \mathrm{U}$ and ${ }^{238} \mathrm{U}$, Phys. Rev. C, 4(5), 1889-1906,10.1103/PhysRevC.4.1889. 
Joseph C, Campbell KA, Torres ME, Martin RA, Pohlman JW, Riedel M, Rose K (2013) Methane-derived authigenic carbonates from modern and paleoseeps on the Cascadia margin: Mechanisms of formation and diagenetic signals. Palaeogeogr. Palaeoclimatol. Palaeoecol. 390:52-67

Lietard C, Pierre C (2008) High-resolution isotopic records $\left(\delta^{18} \mathrm{O}\right.$ and $\left.\delta^{13} \mathrm{C}\right)$ and cathodoluminescence study of lucinid shells from methane seeps of the Eastern Mediterranean. Geo-Mar Lett:195-203

Liebetrau V, Augustin N, Kutterolf S, Schmidt M, Eisenhauer A, Garbe-Schönberg D, Weinrebe W (2014) Coldseep-driven carbonate deposits at the Central American forearc: contrasting evolution and timing in escarpment and mound settings. Int. J. Earth Sci. 103:1845-1872

Matsumoto R (1990) Vuggy carbonate crust formed by hydrocarbon seepage on the continental shelf of Baffin Island, northeast Canada. Geochem J 24:143-158

McHugh CMG, Olson HC (2002) Pleistocene chronology of continental margin sedimentation:: New insights into traditional models, New Jersey. Mar Geol 186:389-411

Naehr TH, Eichhubl P, Orphan VJ, Hovland M, Paull CK, Ussler Iii W, Lorenson TD, Greene HG (2007) Authigenic carbonate formation at hydrocarbon seeps in continental margin sediments: A comparative study. Deep Sea Res II 54:1268-1291

Newman KR, Cormier M-H, Weissel JK, Driscoll NW, Kastner M, Solomon EA, Robertson G, Hill JC, Singh H, Camilli R (2008) Active methane venting observed at giant pockmarks along the US mid-Atlantic shelf break. Earth Planet Sci Lett 267:341-352

NOAA (2012) NOAA explorers discover deepwater gas seeps off U.S. Atlantic coast. Press Release (http://www.noaanews.noaa.gov/stories2012/20121219_gas_seeps.html)

Obelcz J, Brothers D, Chaytor J, Brink Ut, Ross SW, Brooke S (2014) Geomorphic characterization of four shelfsourced submarine canyons along the U.S. Mid-Atlantic continental margin. Deep Sea Res II 104:106-119

Olsson, IU (1970) The use of Oxalic acid as a Standard. In I.U. Olsson, ed., Radiocarbon Variations and Absolute Chronology, Nobel Symposium, 12th Proc., John Wiley \& Sons, New York, p. 17.

Orcutt BN, Sylvan JB, Knab NJ, Edwards KJ (2011) Microbial ecology of the dark ocean above, at, and below the seafloor. Microbiol Mol Biol Rev 75:361-422

Orphan VJ, Ussler W, Naehr TH, House CH, Hinrichs KU, Paull CK (2004) Geological, geochemical, and microbiological heterogeneity of the seafloor around methane vents in the Eel River Basin, offshore California. Chem Geol 205:265-289

Paull CK, Ussler W, Borowski WS, Spiess FN (1995) Methane-rich plumes on the Carolina continental rise: Associations with gas hydrates. Geology 23:89-92

Poag CW (1992) U.S. Middle Atlantic Continental Rise: Provenance, Dispersal, and Deposition of Jurassic to Quaternary Sediments. In: Poag CW, Graciansky PC (eds) Geologic Evolution of Atlantic Continental Rises. Van Nostrand Reinhold, New York, pp100-156

Pohlman JW, Kaneko M, Heuer VB, Coffin RB, Whiticar M (2009) Methane sources and production in the northern Cascadia margin gas hydrate system. Earth Planet Sci Lett 287:504-512

Pohlman, J., C. Ruppel, R. Colwell, S. Krause, T. Treude, M. Graw, M. Casso, L.-G. Boze, B. Buczkowki, and D. Brankovits, 2015, Sediment and water column chemistry related to methane seepage along the northern US Atlantic margin, Fall Meeting Amer. Geophys. Union, OS33A-1992.

Prouty, NG, Swarzenski, Mienis, F., Davies, A.J., Demopoulos, A., Condon, D. Ross, S, and Brooke, S. (2015) Sources of Organic Matter to Deep-sea Corals Living in Submarine Canyons of the Mid-Atlantic Bight Region, U.S. Aquatic Sciences ASLO Meeting, 27449

Quattrini AM, Nizinski MS, Chaytor JD, Demopoulos AWD, Roark EB, France SC, Moore JA, Heyl TP, Auster PJ, Kinlan B, Ruppel C, Elliott KP, Kennedy BRC, Lobecker E, Skarke A, Shank T (2015) Exploration of the Canyon-Incised Continental Margin of the Northeastern United States Reveals Dynamic Habitats and Diverse Communities. PLoS ONE 10(10): e0139904. doi:10.1371/journal.pone.0139904

Robinson FL, Belshaw NS, Henderson GM (2004) U and Th concentrations and isotope ratios in modern carbonates and waters from the Bahamas. Geochim. Cosmochim. Acta. 68:1777-1789

Ruppel C, Kluesner JW, Danforth W (2015a) Imaging Methane Seeps and Plumes on the U.S. Atlantic Margin Sound Waves March June 2015. U.S. Geological Survey http://soundwaves.usgs.gov/2015/06/fieldwork3.html

Ruppel, C, Kluesner, JW, Pohlman J, Brothers D, Colwell F, Krause S. and Treude T. (2015b) Methane Hydrate Dynamics on the US Atlantic Margin. DOE Fire-in-the -Ice 15(2): 10-13.

Sample JC, Reid MR, Tobin HJ, Moore JC (1993) Carbonate cements indicate channeled fluid flow along a zone of vertical faults at the deformation front of the Cascadia accretionary wedge (northwest U.S. coast). Geology 21:507-510 
Schöne BR, Giere O (2005) Growth increment and stable isotope variation in shells of the deep-sea hydrothermal vent bivalve mollusk Bathymodiolus brevior from the North Fiji Basin Pacific Ocean. Deep Sea Res I 52:18961910

Skarke A, Ruppel C, Kodis M, Brothers D, Lobecker E (2014) Widespread methane leakage from the seafloor on the northern US Atlantic margin. Nature Geosci 7:657-661

Stuiver M, Polach HA (1977) Discussion reporting of ${ }^{14} \mathrm{C}$ data. Radiocarbon 19:355-363

Suess E (2014) Marine cold seeps and their manifestations: geological control, biogeochemical criteria and environmental conditions. Int. J. Earth Sci. 103:1889-1916

Teichert BMA, Eisenhauer A, Bohrmann G, Haase-Schramm A, Bock B, Linke P (2003) U/Th systematics and ages of authigenic carbonates from Hydrate Ridge, Cascadia Margin: recorders of fluid flow variations. Geochim Cosmochim Acta 67:3845-3857

ten Brink US, Chaytor JD, Geist EL, Brothers DS, Andrews BD (2014) Assessment of tsunami hazard to the U.S. Atlantic margin. Mar Geol 353:31-54

Van Dover CL, Aharon P, Bernhard JM, Caylor E, Doerries M, Flickinger W, Gilhooly W, Goffredi SK, Knick KE, Macko SA, Rapoport S, Raulfs EC, Ruppel C, Salerno JL, Seitz RD, Sen Gupta BK, Shank T, Turnipseed M, Vrijenhoek R (2003) Blake Ridge methane seeps: characterization of a soft-sediment, chemosynthetically based ecosystem. Deep Sea Res I 50:281-300

Veloso M, Greinert J, Mienert J, De Batist M (2015), A new methodology for quantifying bubble flow rates in deep water using splitbeam echosounders: Examples from the Arctic offshore NW-Svalbard. Limnol Oceanogr: Methods, 13: 267-287. doi: 10.1002/lom3.10024

Vogel JS, Southon JR, Nelson DE (1987) Catalyst and binder effects in the use of filamentous graphite for AMS. Nucl. Instr. Meth. Phys. Res. 29:50-56

Weinstein A, Navarrete L, Leonte M, Weber T, Ruppel C, Kellermann M, Arrington E, Valentine DL, Chepigin A, Rosemore B, Green A, Du M., Scranton MI, Kessler JD (2016) Determining the flux of methane into the Hudson Canyon at the edge of methane clathrate hydrate stability. Geophysical Research Letters, in review

Westbrook GK, Thatcher KE, Rohling EJ, Piotrowski AM, Pälike H, Osborne AH, Nisbet EG, Minshull TA, Lanoisellé M, James RH (2009) Escape of methane gas from the seabed along the West Spitsbergen continental margin. Geophys Res Lett 36

Yamanaka T, Mizota C, Fujiwara Y, Chiba H, Hashimoto J, Gamo T, Okudaira T (2003) Sulphur-isotopic composition of the deep-sea mussel Bathymodiolus marisindicus from currently active hydrothermal vents in the Indian Ocean. J. Mar. Biol. Assoc. U. K. 83:841-848 


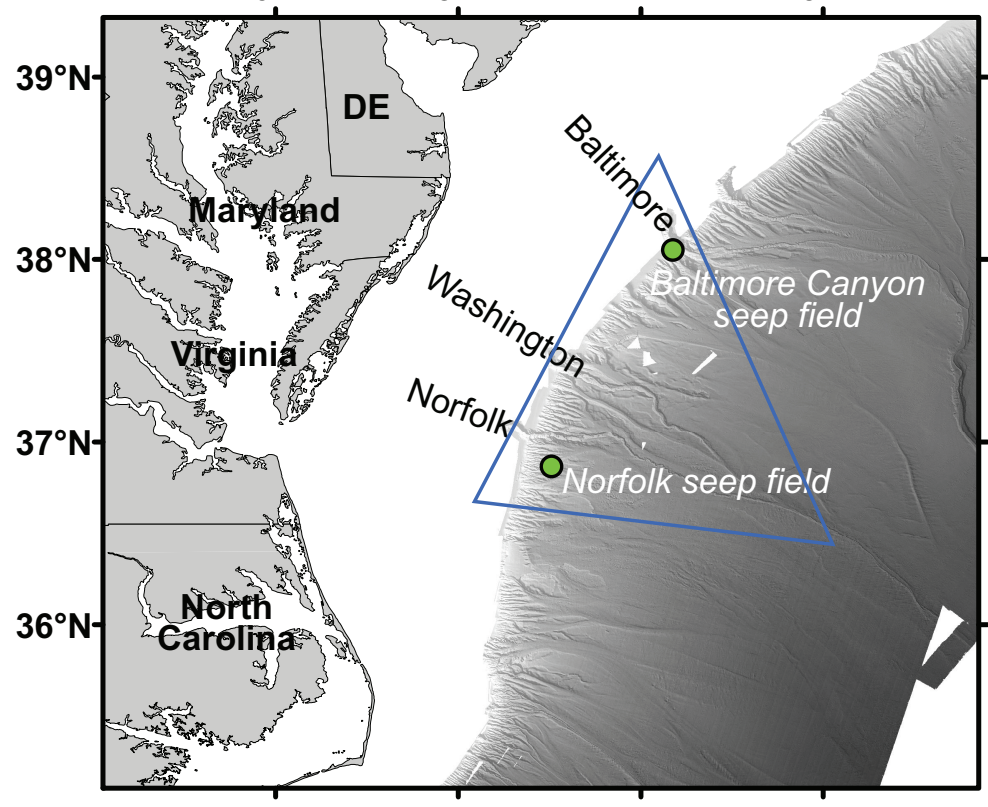

Figure 1, Prouty et al. 

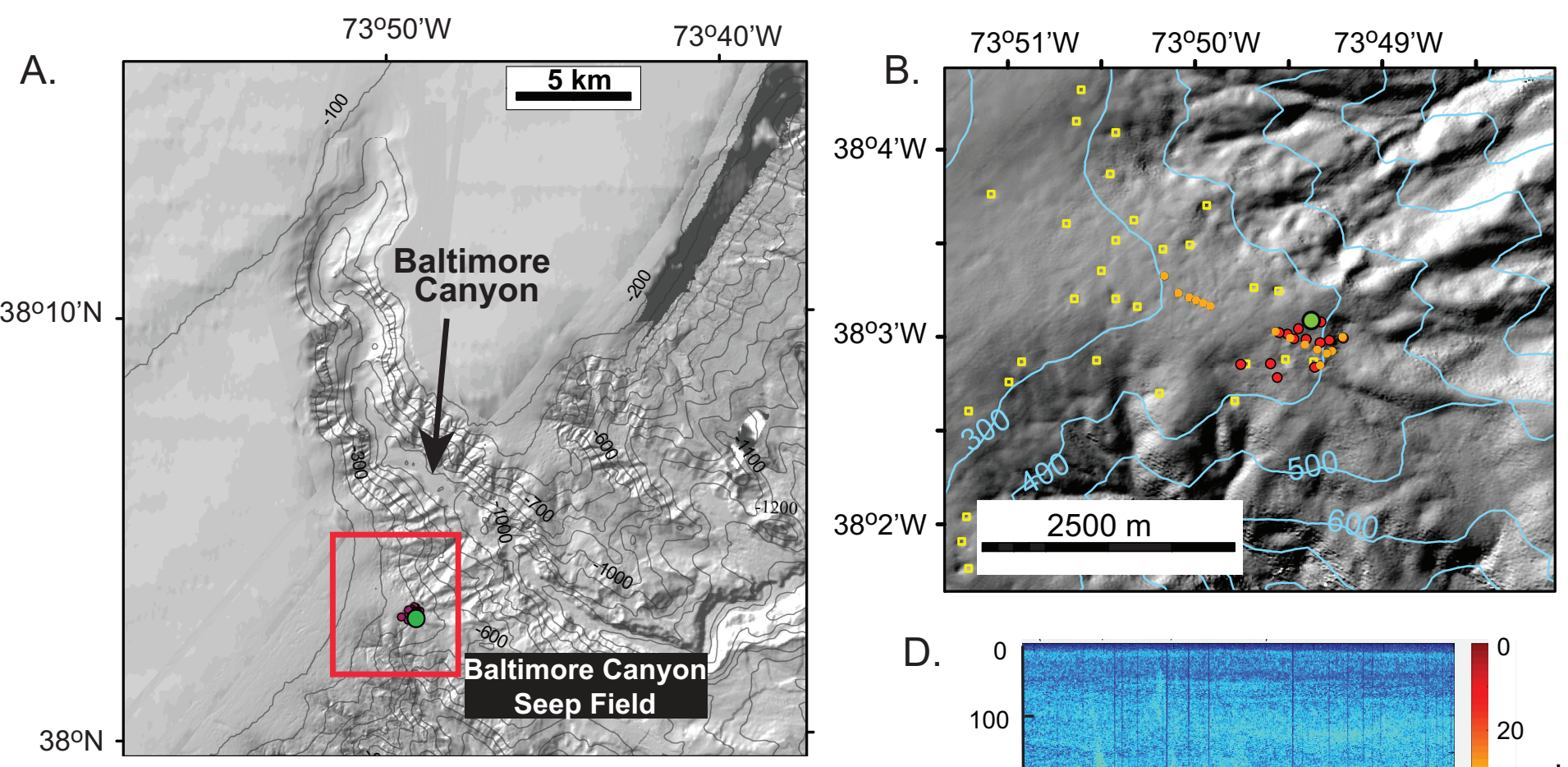

C.
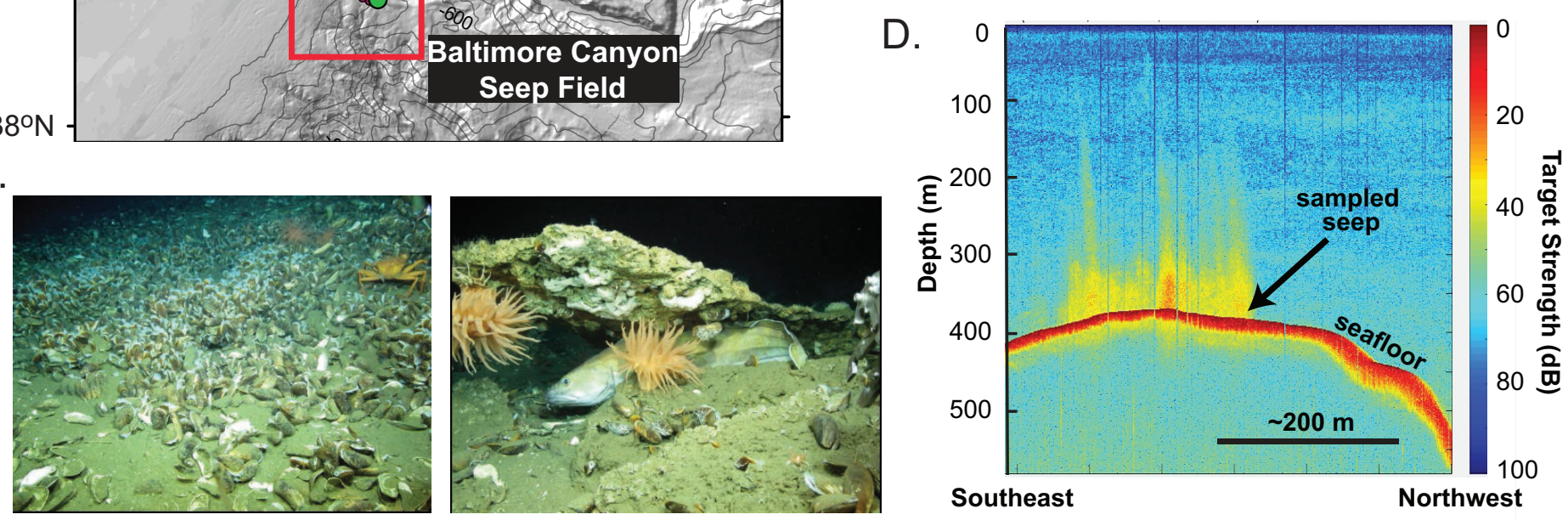

Figure 2, Prouty et al. 
Figure 4, Prouty et al.

Norfolk (RB-2013-682)

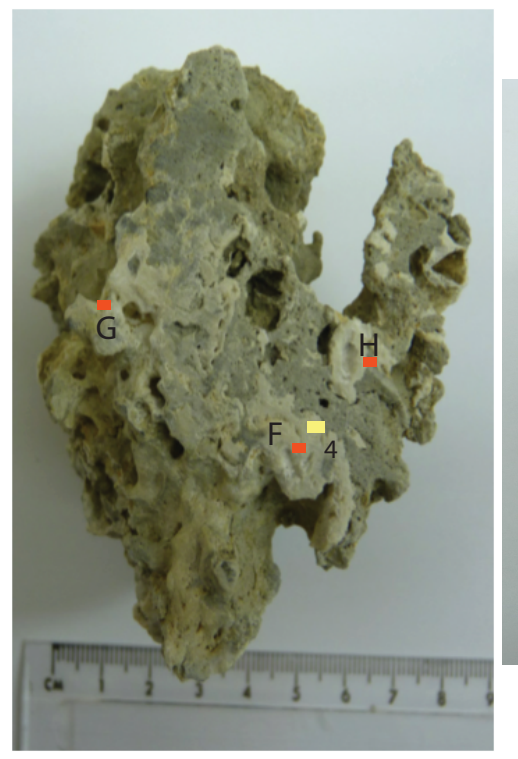

Baltimore Canyon (NF-2012-14)

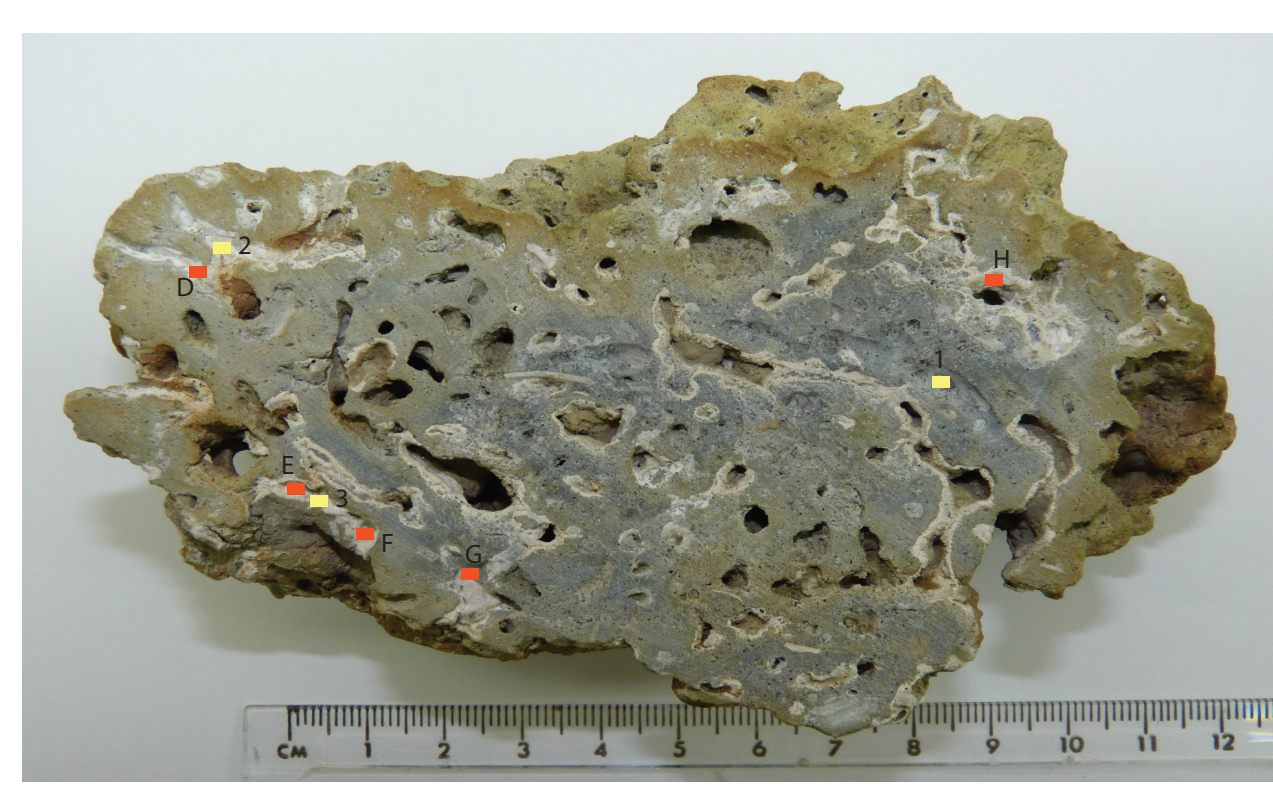

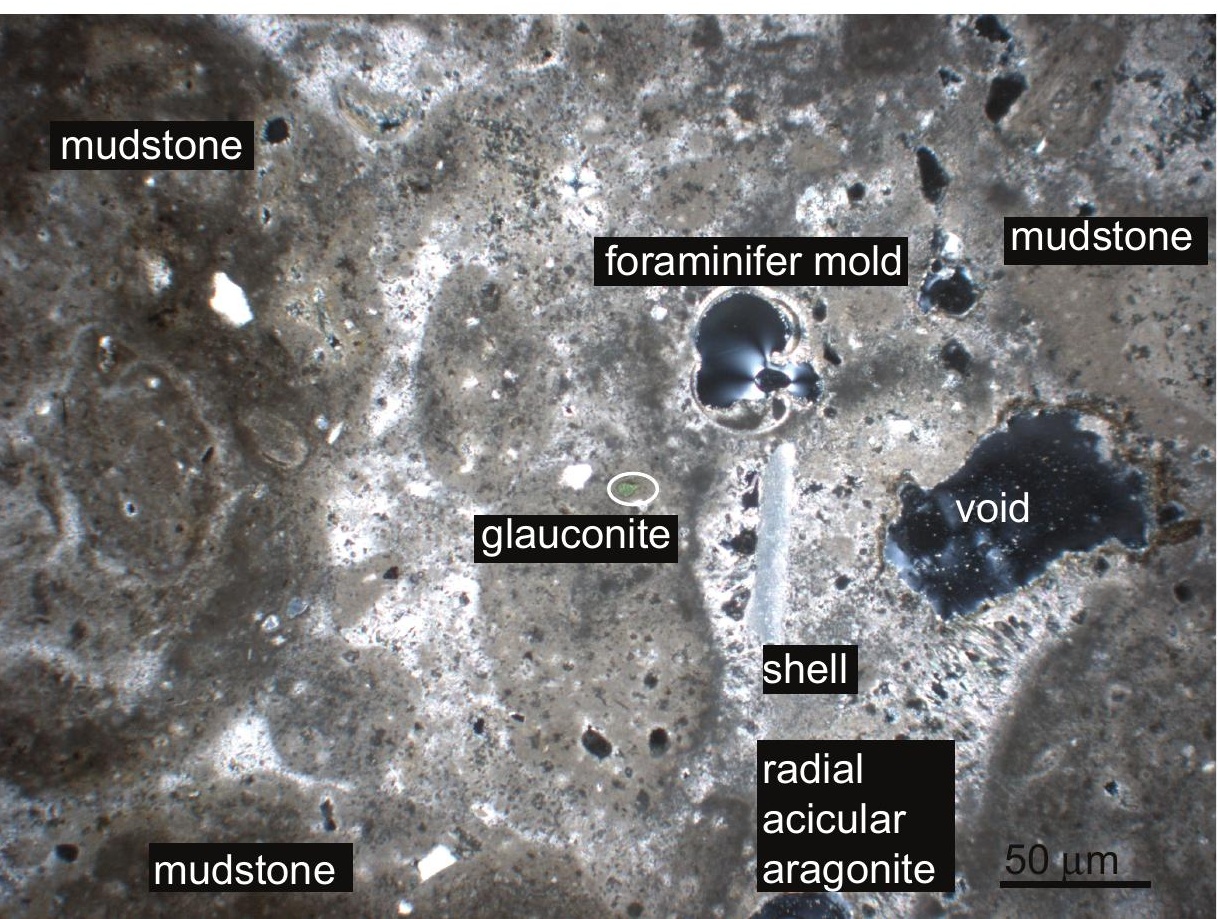

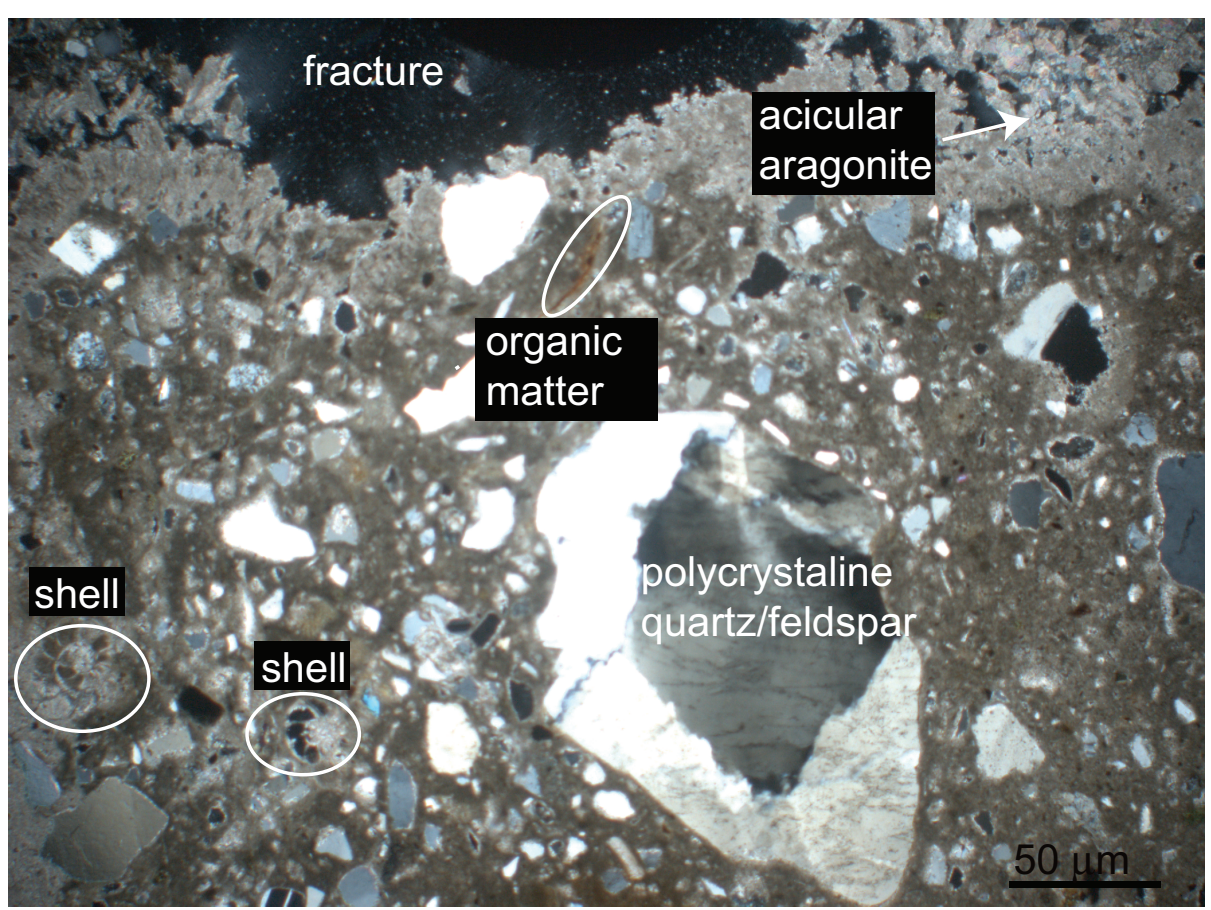




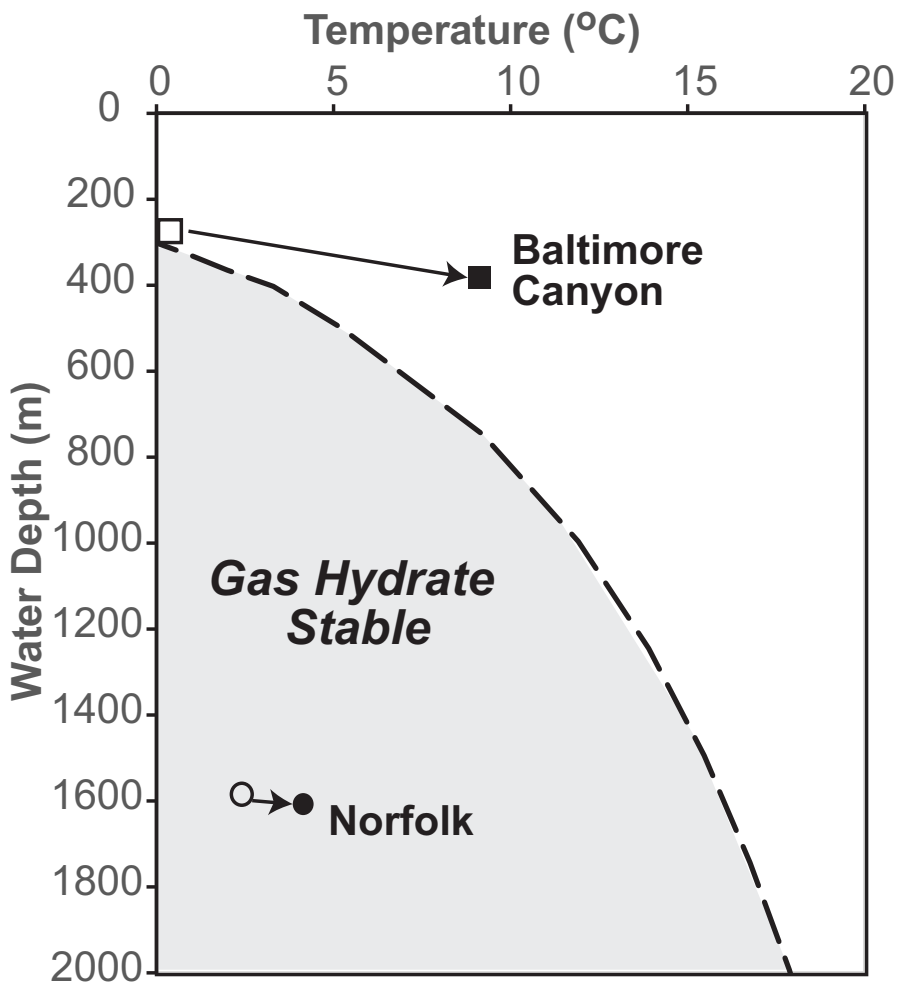

Figure 5, Prouty et al. 


\section{Tables}

\begin{tabular}{lllllll}
\hline & \multicolumn{2}{c}{ Sediment } & \multicolumn{2}{c}{ Cement } & \multicolumn{2}{c}{ Groundmass } \\
\hline & Norfolk & $\begin{array}{l}\text { Baltimore } \\
\text { Canyon }\end{array}$ & Norfolk & $\begin{array}{l}\text { Baltimore } \\
\text { Canyon }\end{array}$ & Norfolk & $\begin{array}{l}\text { Baltimore } \\
\text { Canyon }\end{array}$ \\
\hline Mineral & - & - & Aragonite & Aragonite & Aragonite & Aragonite \\
$\% \mathrm{CaCO}_{3}$ & $13.9 \pm 6.5$ & 3.3 & 97.2 & 85.1 & 72.5 & 47.6 \\
$\% \mathrm{C}_{\text {org }}$ & $3.7 \pm 1.4$ & $0.64 \pm 0.14$ & 0.16 & 0.28 & 0.27 & 0.39 \\
& & & & - & & \\
$\delta^{13} \mathrm{C}(\%)$ & $-31.9 \pm 9.0$ & $-23.4 \pm 3.0$ & $-47.3 \pm 0.16$ & $49.2 \pm 0.21$ & $-44.3 \pm 0.07$ & $-47.7 \pm 0.92$ \\
$\delta^{18} \mathrm{O}(\%)$ & - & - & $3.84 \pm 0.07$ & $4.35 \pm 0.06$ & $3.78 \pm 0.03$ & $3.54 \pm 0.04$ \\
${ }^{87} \mathrm{Sr} /{ }^{86} \mathrm{Sr}$ & - & - & 0.70917 & 0.70918 & 0.70920 & 0.70924 \\
\hline
\end{tabular}

Table 1

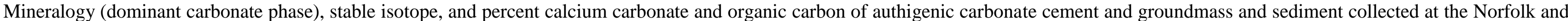

Baltimore canyons seep sites. Average values reported \pm 1 standard deviation. 


\begin{tabular}{|c|c|c|c|c|c|}
\hline & \multicolumn{2}{|l|}{$\begin{array}{c}\text { Mussel } \\
\text { Carbonate Shell }\end{array}$} & \multirow{2}{*}{$\begin{array}{c}\begin{array}{c}\text { Mussel } \\
\text { Periostracum }\end{array} \\
\text { Norfolk }\end{array}$} & \multicolumn{2}{|c|}{ Seawater } \\
\hline & Norfolk & $\begin{array}{l}\text { Baltimore } \\
\text { Canyon }\end{array}$ & & Norfolk & $\begin{array}{l}\text { Baltimore } \\
\text { Canyon }\end{array}$ \\
\hline$\delta^{13} \mathrm{C}(\%)$ & $-2.59 \pm 1.68(-7.10 \pm 3.20)$ & $-6.84 \pm 1.97$ & $-56.99 \pm 12.8$ & $0.90 \pm 0.06$ & - \\
\hline $\min$ & $-6.53(-16.74)$ & -10.91 & -70.66 & 0.86 & \\
\hline $\max$ & $0.19(-3.34)$ & -3.39 & -29.92 & 0.94 & \\
\hline$\delta^{18} \mathrm{O}(\%)$ & $3.71 \pm 0.25(3.82 \pm 0.39)$ & $2.57 \pm 0.28$ & - & $0.34 \pm 0.1$ & $0.53 \pm 0.1$ \\
\hline $\min$ & $3.11(3.46)$ & 2.06 & & & \\
\hline $\max$ & $4.19(5.13)$ & 3.59 & & & \\
\hline${ }^{87} \mathrm{Sr} /{ }^{86} \mathrm{Sr}$ & 0.70920 & - & - & 0.70917 & - \\
\hline $\min$ & 0.70918 & & & 0.70915 & \\
\hline $\max$ & 0.70921 & & & 0.70920 & \\
\hline
\end{tabular}

Table 2

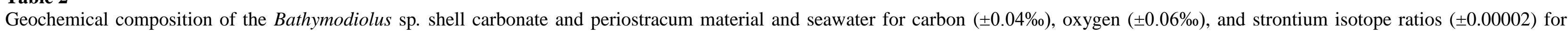
samples collected only at Norfolk. Average and standard deviations are reported. Ranges of values are also reported as minimum and maximum values; values in parenthesis are for dead specimens collected at Norfolk. 


\begin{tabular}{llllll}
\hline \multicolumn{2}{c}{ Gill } & \multicolumn{2}{c}{ Periostracum } & \multicolumn{2}{c}{ Sediment } \\
\hline & Norfolk Seep & Baltimore Canyon & Seep & Norfolk Seep & Norfolk Seep \\
\hline Average $( \pm \sigma)$ & $16.58 \pm 3.37$ & $14.38 \pm 5.15$ & $16.63 \pm 4.01$ & $13.89 \pm 1.24$ & $5.53 \pm 2.16$ \\
Range & $8.65-21.55$ & $-4.07-18.13$ & $8.82-22.65$ & $13.01-14.77$ & $2.98-8.20$ \\
$\mathrm{n}$ & 23 & 20 & 28 & 2 & $-2.42 \pm 3.62$ \\
\hline
\end{tabular}

Table 3

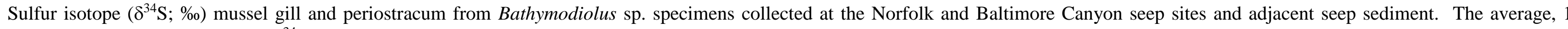
standard deviation, and ranges of $\delta^{34} S$ values are reported. 


\begin{tabular}{|c|c|c|c|c|c|c|c|c|c|}
\hline Station no. & Sample ID & Seep Field Site & Sample type & Fm & \pm Fm Err & Age & Age Err & $\Delta^{14} \mathrm{C}(\%)$ & $\pm \Delta^{14} \mathrm{C}$ Err \\
\hline RB-13-ROV-682 & RB-13-682-1 & Norfolk Canyon & authigenic carbonate-groundmass & 0.1136 & 0.0010 & 17480 & 80 & -887.3 & 1.0 \\
\hline RB-13-ROV-682 & RB-13-682-2 & Norfolk Canyon & authigenic carbonate -cement & 0.1046 & 0.0010 & 18140 & 80 & -896.2 & 1.0 \\
\hline RB-13-ROV-682 & RB-13-682-3 & Norfolk Canyon & authigenic carbonate -cement & 0.1175 & 0.0010 & 17200 & 80 & -883.4 & 1.0 \\
\hline RB-13-ROV-682 & RB-13-682-4 & Norfolk Canyon & authigenic carbonate -cement & 0.0925 & 0.0010 & 19120 & 90 & -908.2 & 1.0 \\
\hline RB-13-ROV-682 & RB-13-682-5 & Norfolk Canyon & shell in authigenic carbonate & 0.6094 & 0.0013 & 3980 & 20 & -395.3 & 1.3 \\
\hline RB-13-ROV-682 & RB-13-682-6 & Norfolk Canyon & shell in authigenic carbonate & 0.6112 & 0.0013 & 3955 & 20 & -393.5 & 1.3 \\
\hline NF-12-ROV-14 & NF-12-14-1 & Baltimore Canyon & authigenic carbonate-groundmass & 0.0670 & 0.0010 & 21710 & 130 & -933.5 & 1.0 \\
\hline NF-12-ROV-14 & NF-12-14-2 & Baltimore Canyon & authigenic carbonate -cement & 0.0414 & 0.0010 & 25570 & 210 & -958.9 & 1.0 \\
\hline NF-12-ROV-14 & NF-12-14-3 & Baltimore Canyon & authigenic carbonate -cement & 0.2617 & 0.0011 & 10770 & 35 & -740.3 & 1.1 \\
\hline RB-13-ROV-689 & RB-13-ROV-689-M6 & Baltimore Canyon & mussel shell (alive) & 0.8782 & 0.0017 & 1045 & 20 & -128.6 & 1.7 \\
\hline RB-13-ROV-689 & RB-13-ROV-689-M6 (rep) & Baltimore Canyon & mussel shell (alive) & 0.8747 & 0.0017 & 1075 & 20 & -132.0 & 1.7 \\
\hline RB-13-ROV-689 & RB-13-ROV-689-M10 & Baltimore Canyon & mussel shell (alive) & 0.7859 & 0.0015 & 1935 & 20 & -220.2 & 1.5 \\
\hline RB-13-ROV-687 & RB-13-ROV-687 & Norfolk Canyon & mussel shell (dead) & 0.8114 & 0.0016 & 1680 & 20 & -194.9 & 1.6 \\
\hline RB-13-ROV-687 & RB-13-ROV-687 (rep) & Norfolk Canyon & mussel shell (dead) & 0.8078 & 0.0017 & 1715 & 20 & -198.5 & 1.7 \\
\hline RB-13-ROV-683 & RB-13-ROV-683-Q16A & Norfolk Canyon & mussel shell (dead) & 0.7802 & 0.0015 & 1995 & 20 & -225.8 & 1.5 \\
\hline RB-13-ROV-682 & RB-13-ROV-682-MQ9 & Norfolk Canyon & mussel shell (dead) & 0.8558 & 0.0021 & 1250 & 20 & -150.8 & 2.1 \\
\hline RB-13-ROV-682 & RB-13-ROV-682- MQ8 & Norfolk Canyon & mussel shell (dead) & 0.9094 & 0.0017 & 765 & 15 & -97.6 & 1.7 \\
\hline RB-13-ROV-682 & RB-13-ROV-682 & Norfolk Canyon & mussel shell (dead) & 0.8667 & 0.0018 & 1150 & 20 & -140.0 & 1.8 \\
\hline RB-13-ROV-682 & RB-13-ROV-682 & Norfolk Canyon & mussel shell (dead) & 0.8632 & 0.0021 & 1180 & 20 & -143.5 & 2.1 \\
\hline RB-13-ROV-682 & RB-13-ROV-682 10\% HCl* & Norfolk Canyon & mussel shell (dead) & 0.8622 & 0.0018 & 1190 & 20 & -144.5 & 1.8 \\
\hline RB-13-ROV-682 & RB-13-ROV-682 10\% $\mathrm{HCl}^{*}$ & Norfolk Canyon & mussel shell (dead) & 0.8624 & 0.0018 & 1190 & 20 & -144.2 & 1.8 \\
\hline RB-13-ROV-683 & RB-13-ROV-683-M3 & Norfolk Canyon & mussel shell (alive) & 0.8937 & 0.0017 & 905 & 20 & -113.2 & 1.7 \\
\hline RB-13-ROV-683 & RB-13-ROV-683-M17 & Norfolk Canyon & mussel shell (alive) & 0.8898 & 0.0018 & 940 & 20 & -117.1 & 1.8 \\
\hline RB-13-ROV-683 & RB-13-ROV-683-49 & Norfolk Canyon & seawater & 0.9837 & 0.0037 & 130 & 30 & -23.7 & 1.7 \\
\hline RB-13-ROV-682 & RB-13-ROV-682-2 & Norfolk Canyon & seawater & 0.9829 & 0.0027 & 140 & 20 & -24.6 & 1.8 \\
\hline
\end{tabular}

\section{Table 4}

Summary data results for radiocarbon analysis including ROV station number (Station no.), sample identification (Sample ID), laboratory identification number (Lab ID), seep field, sample type, fraction modern (Fm) relative to standard, fraction modern error, ${ }^{14} \mathrm{C}$ age, ${ }^{14} \mathrm{C}$ age error, $\Delta{ }^{14} \mathrm{C}$ value as defined in Stuiver and Polach (1977), and $\Delta{ }^{14} \mathrm{C}$ error. Fraction Modern (Fm) is a measurement 
of the deviation of the ${ }^{14} \mathrm{C} /{ }^{12} \mathrm{C}$ ratio of a sample from "Modern." Modern is defined as 95\% of the radiocarbon concentration (in AD 1950) of NBS Oxalic Acid I normalized to $\delta^{13} \mathrm{C}$ VPDB $=-19$ per mil (Olsson 1970). *Samples pretreated with $10 \% \mathrm{HCl}$

MEASURED

\begin{tabular}{|c|c|c|c|c|c|c|c|}
\hline Sample Name & $\begin{array}{c}\mathrm{Wt} \\
(\mathrm{mg})\end{array}$ & $\underset{(\mathbf{p p m})}{\mathbf{U}}$ & $\begin{array}{c}\text { 232Th } \\
(\mathbf{p p b})\end{array}$ & $\begin{array}{c}{ }^{230} \mathrm{Th} /{ }^{232} \mathrm{Th} \\
\mathbf{A R}(\mathrm{a}) \\
\end{array}$ & ${ }^{232} \mathbf{T h} /{ }^{238} \mathbf{U} \mathbf{A R}_{(\mathrm{a})}$ & $\begin{array}{c}{ }^{230} \mathbf{T h} /{ }^{238} \mathbf{U} \\
\mathbf{A R} \\
(\text { (a) }\end{array}$ & ${ }^{234} \mathbf{U} /{ }^{238} \mathbf{U} \mathbf{A} \mathbf{R}_{(\mathbf{a})}$ \\
\hline \multicolumn{8}{|l|}{ Carbonate samples } \\
\hline \multicolumn{8}{|l|}{ Norfolk Canyon } \\
\hline RB-13-682 D & 8.8 & $3.223 \pm 0.037$ & $271 \pm 3$ & $2.413 \pm 0.015$ & $0.02766 \pm 0.00002$ & $0.0668 \pm 0.0004$ & $1.143 \pm 0.001$ \\
\hline RB-13-682 E & 16.6 & $3.393 \pm 0.021$ & $261 \pm 2$ & $2.776 \pm 0.012$ & $0.02524 \pm 0.00002$ & $0.0701 \pm 0.0003$ & $1.143 \pm 0.001$ \\
\hline RB-13-682 F & 12.3 & $3.427 \pm 0.028$ & $65 \pm 1$ & $3.844 \pm 0.028$ & $0.00623 \pm 0.00001$ & $0.0240 \pm 0.0002$ & $1.145 \pm 0.001$ \\
\hline RB-13-682 G & 17.2 & $4.209 \pm 0.025$ & $209 \pm 1$ & $2.218 \pm 0.012$ & $0.01632 \pm 0.00001$ & $0.0362 \pm 0.0002$ & $1.143 \pm 0.001$ \\
\hline RB-13-682 H & 14.2 & $3.670 \pm 0.026$ & $160 \pm 1$ & $2.231 \pm 0.014$ & $0.01435 \pm 0.00001$ & $0.0320 \pm 0.0002$ & $1.143 \pm 0.001$ \\
\hline \multicolumn{8}{|l|}{ Baltimore Canyon } \\
\hline NF12-14 D & 13.0 & $3.894 \pm 0.030$ & $344 \pm 3$ & $5.835 \pm 0.017$ & $0.02899 \pm 0.00002$ & $0.1692 \pm 0.0006$ & $1.139 \pm 0.001$ \\
\hline NF12-14 E & 4.7 & $4.073 \pm 0.087$ & $241 \pm 5$ & $8.585 \pm 0.036$ & $0.01941 \pm 0.00001$ & $0.1667 \pm 0.0008$ & $1.140 \pm 0.002$ \\
\hline NF12-14 F & 6.4 & $4.592 \pm 0.072$ & $268 \pm 4$ & $8.342 \pm 0.029$ & $0.01916 \pm 0.00001$ & $0.1598 \pm 0.0006$ & $1.141 \pm 0.001$ \\
\hline NF12-14 G & 4.1 & $4.588 \pm 0.112$ & $433 \pm 11$ & $5.682 \pm 0.023$ & $0.03103 \pm 0.00002$ & $0.1763 \pm 0.0008$ & $1.139 \pm 0.002$ \\
\hline NF12-14 H & 6.9 & $4.110 \pm 0.060$ & $586 \pm 9$ & $4.087 \pm 0.013$ & $0.04681 \pm 0.00002$ & $0.1913 \pm 0.0007$ & $1.136 \pm 0.002$ \\
\hline \multicolumn{8}{|l|}{ Detritus samples } \\
\hline \multicolumn{8}{|l|}{ Norfolk Canyon } \\
\hline RB13-D682-PC03 A & 77.1 & $1.959 \pm 0.003$ & $8167 \pm 14$ & $1.509 \pm 0.003$ & $1.36986 \pm 0.00113$ & $2.0674 \pm 0.0052$ & $0.989 \pm 0.001$ \\
\hline RB13-D682-PC03 B & 142.9 & $1.764 \pm 0.002$ & $7403 \pm 12$ & $1.492 \pm 0.003$ & $1.37909 \pm 0.00172$ & $2.0576 \pm 0.0057$ & $0.989 \pm 0.001$ \\
\hline RB13-D682-PC03 C & 134.6 & $1.858 \pm 0.002$ & $7865 \pm 27$ & $1.467 \pm 0.007$ & $1.39116 \pm 0.00451$ & $2.0403 \pm 0.0089$ & $0.990 \pm 0.001$ \\
\hline RB13-D682-PC04 A & 75.6 & $2.165 \pm 0.003$ & $7166 \pm 12$ & $1.588 \pm 0.003$ & $1.08744 \pm 0.00082$ & $1.7272 \pm 0.0042$ & $1.012 \pm 0.001$ \\
\hline RB13-D682-PC04 B & 82.1 & $2.486 \pm 0.003$ & $8597 \pm 15$ & $1.556 \pm 0.004$ & $1.13645 \pm 0.00125$ & $1.7682 \pm 0.0050$ & $1.008 \pm 0.001$ \\
\hline \multicolumn{8}{|l|}{ Baltimore Canyon } \\
\hline NF12-14 1 & 11.1 & $2.756 \pm 0.025$ & $18081 \pm 164$ & $0.680 \pm 0.001$ & $2.15602 \pm 0.00178$ & $1.4664 \pm 0.0037$ & $0.993 \pm 0.001$ \\
\hline NF12-14 2 & 15.0 & $1.990 \pm 0.013$ & $8551 \pm 57$ & $0.936 \pm 0.002$ & $1.41179 \pm 0.00069$ & $1.3208 \pm 0.0034$ & $0.995 \pm 0.001$ \\
\hline NF12-071-185 B & 126.5 & $1.118 \pm 0.001$ & $4119 \pm 9$ & $1.118 \pm 0.005$ & $1.21060 \pm 0.00220$ & $1.3530 \pm 0.0058$ & $1.000 \pm 0.001$ \\
\hline NF12-071-185 C & 107.6 & $1.237 \pm 0.001$ & $5799 \pm 8$ & $0.843 \pm 0.002$ & $1.54106 \pm 0.00123$ & $1.2984 \pm 0.0035$ & $0.994 \pm 0.001$ \\
\hline
\end{tabular}

NF12-071-185 C $\quad 107.6 \quad 1.237 \pm 0.001 \quad 5799 \pm 8$
CORRECTED

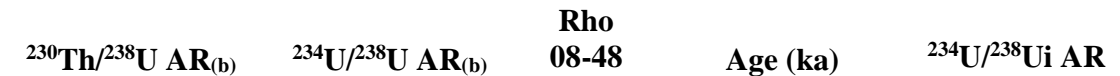




\section{Table 5}

Summary data for measured U-Th data for authigenic carbonate samples and activity ratios (AR) used for age calculation and U-Th ages. All activity ratios were calculated using $\lambda^{230}=9.17050 \mathrm{E}-6$, $\lambda^{234}=2.82206 \mathrm{E}-6$ (Cheng et al., 2013), $\lambda^{232}=4.93343 \mathrm{E}-11$ (Holden et al., 1990), $\lambda^{238}=1.55125 \mathrm{E}-10$ (Jaffey et al., 1971), (a) - Activity ratios corrected for hydride formation, tailing, fractionation, SEM-Faraday yield, and tracer isotopic composition, (b) Corrected using average measured detrital $\mathrm{U}$ and $\mathrm{Th}$ isotopic compositions for the Norfolk Canyon $\left(\left({ }^{232} \mathrm{Th} /{ }^{238} \mathrm{U}\right)=1.38,\left({ }^{230} \mathrm{Th} /{ }^{238} \mathrm{U}\right)=2.05\right.$ and $\left.\left({ }^{234} \mathrm{U} /{ }^{238} \mathrm{U}\right)=0.99, \mathrm{n}=3\right)$ and Baltimore Canyon $\left(\left({ }^{232} \mathrm{Th} /{ }^{238} \mathrm{U}\right)=1.39,\left({ }^{230} \mathrm{Th} /{ }^{238} \mathrm{U}\right)=1.32\right.$ and $\left({ }^{234} \mathrm{U} /{ }^{238} \mathrm{U}\right)=1.00, \mathrm{n}=3$ ) sites with all uncertainties arbitrarily set at $\pm 25 \%$ (see main text section 3.5 for details) 